I N T ER N ATIONAL MONETARY FUND

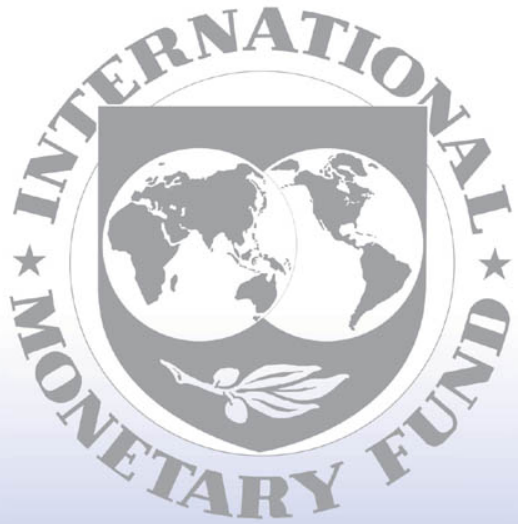

Staff

Country

Reports 


\title{
Gabon: 2010 Article IV Consultation-Staff Report; Staff Supplement; Public Information Notice on the Executive Board Discussion; and Statement by the Executive Director for Gabon
}

Under Article IV of the IMF's Articles of Agreement, the IMF holds bilateral discussions with members, usually every year. In the context of the Article IV consultation with Gabon, the following documents have been released and are included in this package:

- $\quad$ The staff report for the 2010 Article IV consultation, prepared by a staff team of the IMF, following discussions that ended on November 21, 2011, with the officials of Gabon on economic developments and policies. Based on information available at the time of these discussions, the staff report was completed on February 2, 2011. The views expressed in the staff report are those of the staff team and do not necessarily reflect the views of the Executive Board of the IMF.

- A staff supplement of February 2, 2011 updating information on recent developments.

- $\quad$ A Public Information Notice (PIN) summarizing the views of the Executive Board as expressed during its February 18, 2011 discussion of the staff report that concluded the Article IV consultation.

- $\quad$ A statement by the Executive Director for Gabon.

The policy of publication of staff reports and other documents allows for the deletion of market-sensitive information.

\author{
Copies of this report are available to the public from \\ International Monetary Fund • Publication Services \\ $70019^{\text {th }}$ Street, N.W. • Washington, D.C. 20431 \\ Telephone: (202) 623-7430 • Telefax: (202) 623-7201 \\ E-mail: publications@imf.org Internet: http://www.imf.org
}

\section{International Monetary Fund \\ Washington, D.C.}


INTERNATIONAL MONETARY FUND

GABON

\section{Staff Report for the 2010 Article IV Consultation}

Prepared by the Staff Representatives for the 2010 Consultation with Gabon

Approved by Sharmini Coorey and Dhaneshwar Ghura

February 2, 2011

- Mission: A staff team comprising Messrs. Akitoby (head), Gueye, Ms. Dieterich (all AFR), and Mr. Belhocine (FAD) visited Libreville November 12-21, 2010.

Mr. Tsouck Ibounde (World Bank) participated in the meetings.

- Stand-By Arrangement: The Executive Board approved a three-year Stand-By Arrangement for SDR 77.15 million (50 percent of quota) on May 7, 2007. The Arrangement expired in May 2010, with only the first three reviews completed. Recurrent fiscal slippages have made it difficult in the past to sustain Fund-supported programs.

- Past advice: In concluding the 2008 Article IV consultation, Executive Directors commended the authorities for strengthening economic policies, which, together with a favorable external environment, helped deliver high non-oil growth, moderate inflation, and a strong external position. While noting progress made in improving the fiscal position, they emphasized the need for further fiscal consolidation and structural reforms to mitigate risks to macroeconomic stability and prepare Gabon's transition to the post-oil era.

- Exchange Rate Regime: Gabon is a member of the Central African Economic and Monetary Community (CEMAC). The regional currency, the CFA franc, is pegged to the euro. Gabon has accepted the obligations of Article VIII, Sections 2, 3, and 4 of the IMF Articles of Agreement. However, owing to the imposition of a tax on all wire transfers, including for making payments and transfers for current international transactions, Gabon maintains an exchange restriction subject to Fund approval under Article VIII, Section 2 (a) of the Articles of Agreement.

- Data provision: Gabon participates in the General Data Dissemination System (GDDS); data provision is generally adequate for surveillance. 


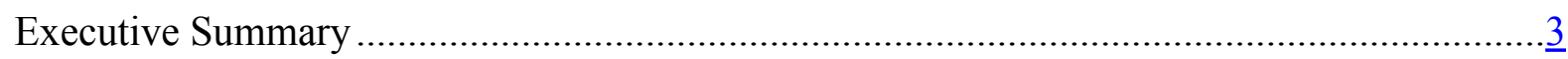

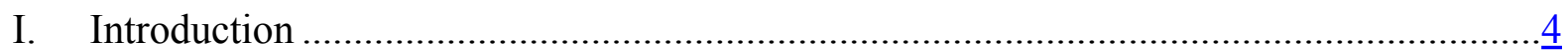

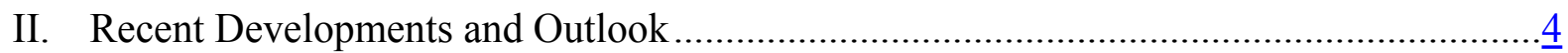

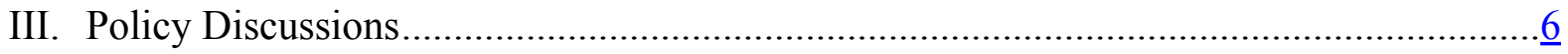

A. Ensuring Fiscal Sustainability and External Competitiveness................................... $\underline{6}$

B. Accelerating Growth to Prepare for the Post-oil Era .............................................11

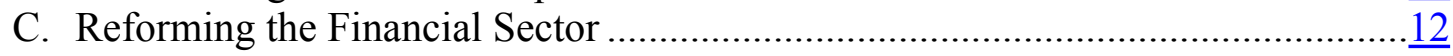

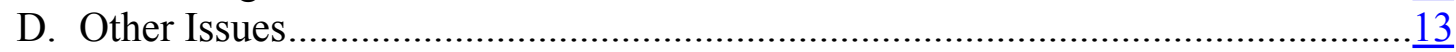

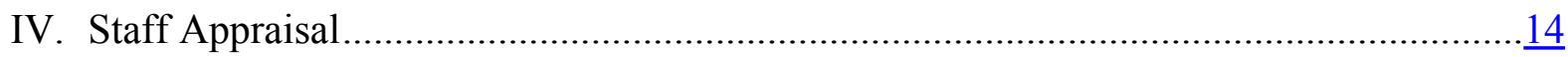

Tables

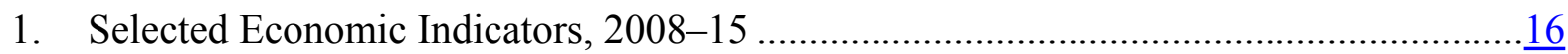

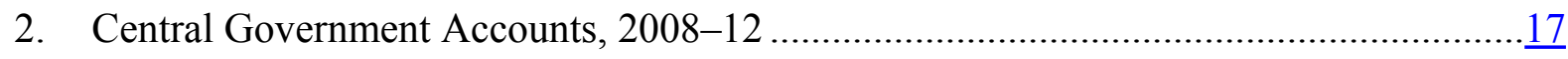

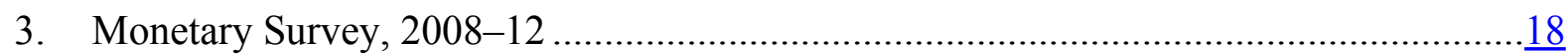

4. Financial Soundness Indicators for the Banking Sector, 2003-10 …...........................19

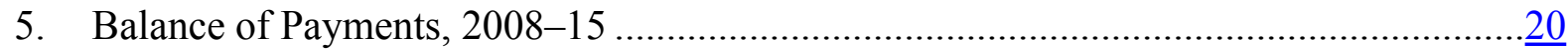

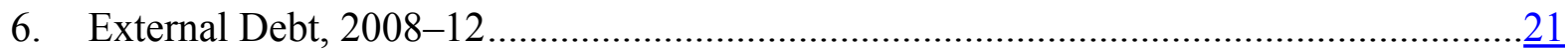

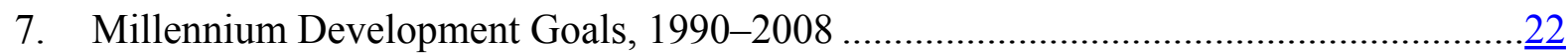

Box

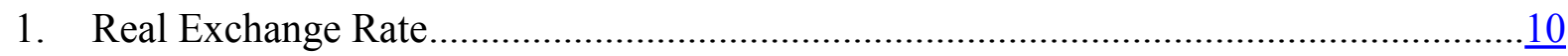

Appendixes

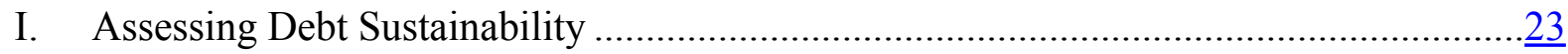




\section{EXECUTIVE SUMMARY}

Background: Low prices and weak demand for commodities shrank the fiscal and current account surpluses in 2009 and turned growth moderately negative. Real GDP is forecast to increase to 5.7 percent in 2010 and remain broadly at that level in 2011, reflecting public investment and a rebound in mining. Over the long term, dwindling oil reserves will cause a decline in income and fiscal revenues, unless non-oil GDP growth accelerates. The government therefore announced a plan to transform Gabon into an emerging economy through diversification away from oil and promotion of a business friendly environment. It has embarked on an ambitious public investment program that will deteriorate the near-term fiscal position.

Challenges: Against the background of the government's economic agenda, policy discussions focused on three key challenges: (i) ensuring fiscal sustainability and external competitiveness because of dwindling oil reserves over the long term, (ii) accelerating growth to prepare for the post-oil era, and (iii) reforming the financial sector.

Staff views: Sustained fiscal consolidation is vital to long-term growth and fiscal sustainability as oil production dwindles over the long term. The government's ambitious capital budget should be anchored in a credible medium-term fiscal strategy to safeguard macroeconomic stability even if oil prices decline. Better public financial management is needed to improve the quality of spending and release resources for growth-enhancing spending and social outlays. With oil reserves depleting, reforms are critical for promoting and diversifying private sector non-oil growth. The priorities are to improve the business climate, build basic infrastructure, and facilitate access to financing for small and mediumsize enterprises (SMEs).

Authorities' views: The authorities agreed with the staff's assessment. They are working on a medium-term framework to bring the deficit down to a sustainable level by reducing capital spending gradually, reforming public wage and employment policies, and rationalizing current spending. They emphasized that forceful implementation of public financial management reforms will help improve spending efficiency. The authorities agreed on the need to reform the business environment and indicated that a service agreement signed with the World Bank will help the government identify priority actions. They also emphasized ongoing initiatives to facilitate SME access to financial services. Key initiatives include reforming disputes settlement, streamlining procedures for guarantees, and establishing a corporate balance sheet centralization system. 


\section{INTRODUCTION}

1. Oil production over the last 40 years has transformed Gabon into a middleincome country; but income inequality is high, and noncommodity sectors are stagnant. Gabon is among the highest per capita GDP countries in Africa but ranks below the average of middle-income countries on human development indicators. Moreover, government spending has often been inefficient. The richest quintile of the population receives half of national income, yet one-third live in poverty. Oil revenue, channeled through government

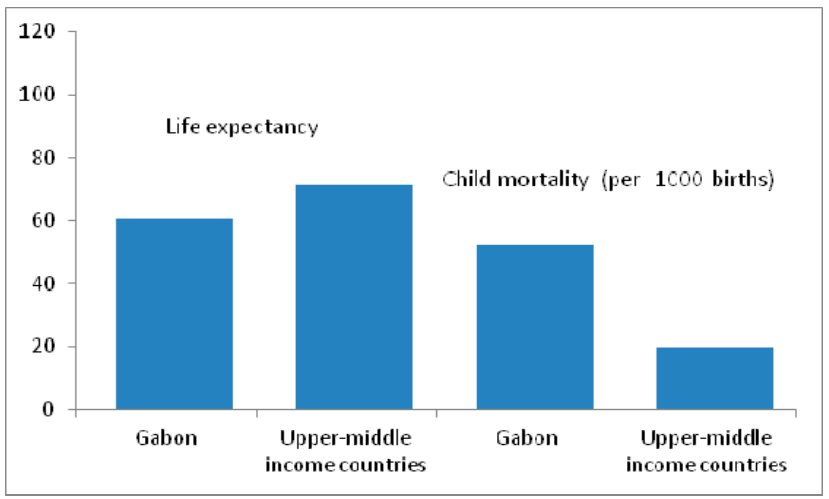
spending, is a main driver of economic activity, but its volatility and pro-cyclical fiscal policy have caused boom and bust cycles that have been exacerbated at times by rapidly rising and downwardly inflexible wages in the context of a fixed exchange rate regime.

2. Gabon went through a political transition in 2009. Ali Bongo Ondimba, the son of the late President Omar Bongo Ondimba, won the August 2009 presidential election. Parliamentary elections are scheduled for November 2011.

3. The newly elected president's plans are to transform Gabon into an emerging economy through diversification away from oil and promotion of a business friendly environment. Dwindling oil reserves will cause a decline in income and fiscal revenues over the long term, unless non-oil GDP growth accelerates. Seeking to increase non-oil potential output, the government has embarked on an ambitious investment plan that will test the country's limited administrative capacity.

\section{RECENT DEVELOPMENTS AND OUTLOOK}

4. Performance under the Fund-supported program was mixed. The three-year Stand-By Arrangement expired in May 2010, with only the first three reviews completed. Recurrent fiscal slippages have made it difficult to sustain Fund-supported programs. The non-oil primary deficit (NOPD) increased significantly from 14 percent of non-oil GDP (NOGDP) in 2009 to about 21 percent of NOGDP in 2010, reflecting higher government investment and wages.

5. Gabon is recovering from the global financial crisis. Low prices and weak demand for commodities shrank the current account and fiscal surpluses in 2009 and turned growth moderately negative. Real GDP is forecast to increase to about 5.7 percent in 2010, reflecting increased public investment and a rebound in mining. Average annual inflation is projected to remain subdued (Table 1). 
6. Staff expects the recovery to be sustained, with downside risks from commodity prices and possible slippages in policy implementation. Economic activity is projected to remain robust in 2011, supported by mining, wood processing, and public investment. Inflation is forecast to pick up, mostly driven by higher food and energy prices. The foremost risk to the economic outlook is a decline in oil and manganese prices, because these commodities accounted for about 90 percent of total exports of goods and 45 percent of nominal GDP on average during the last decade. Plans to further increase investment spending in 2011 would be procyclical and increase the risk of a sudden reversal in policies, if commodity prices declined. Politically, ongoing episodic strikes for higher wages and social benefits could intensify ahead of the parliamentary elections.

Gabon: Fiscal Developments, 2005-11

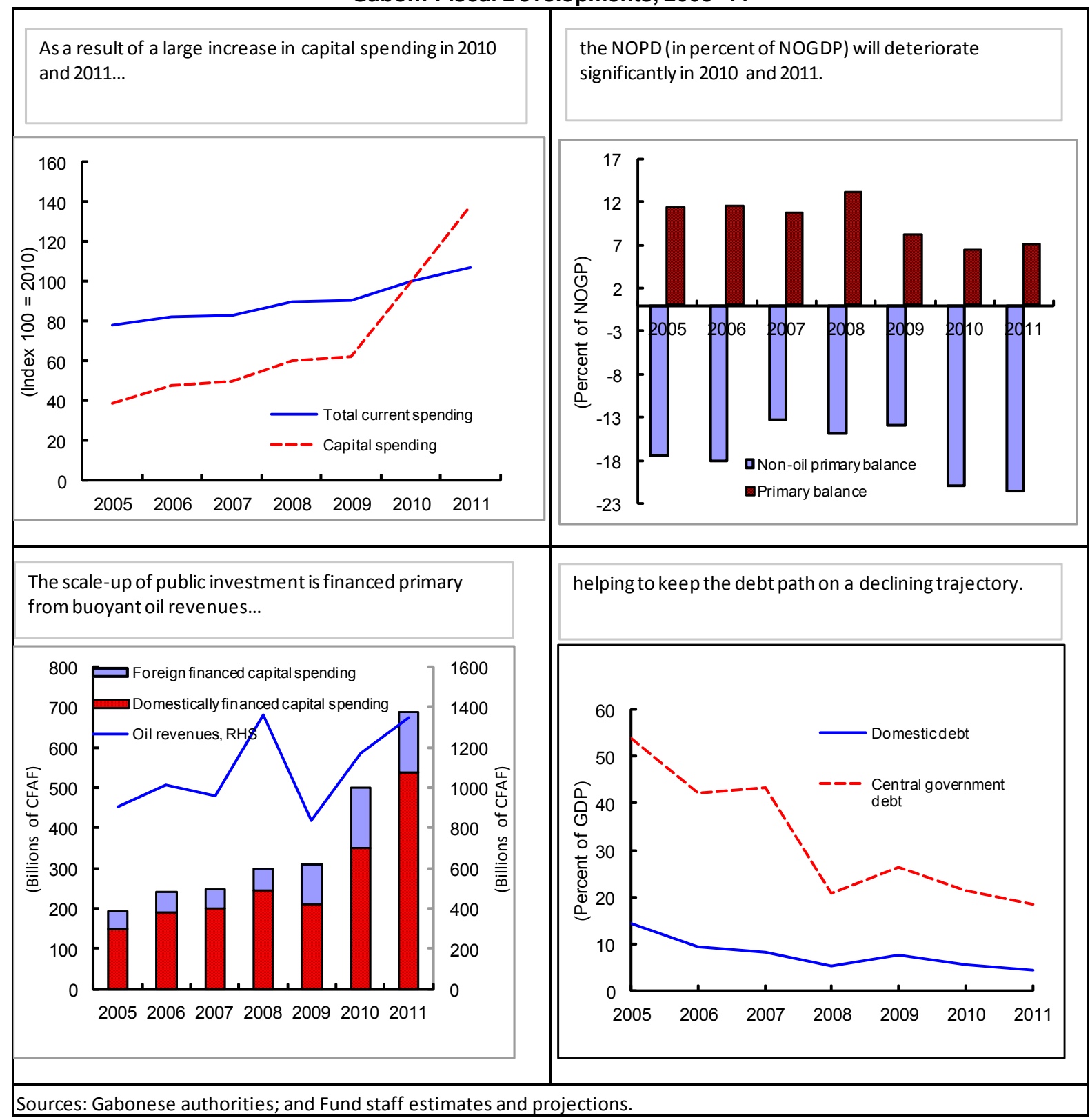




\section{Policy Discussions}

7. Against the background of the government's plan to transform Gabon into an emerging economy, policy discussions focused on three key themes: (i) ensuring fiscal sustainability and external competitiveness because of dwindling oil reserves over the long term, (ii) accelerating growth to prepare for the post-oil era, and (iii) reforming the financial sector.

\section{A. Ensuring Fiscal Sustainability and External Competitiveness}

\section{Macrofiscal policies}

8. After the strong increase in spending in 2010, the 2011 draft budget includes a further acceleration of capital spending, which will worsen the gap with the sustainable NOPD. ${ }^{1}$ The increase in capital spending would be partly offset by a decline in current spending (in percent of NOGDP). In particular, goods and services expenses are projected to rise only in line with inflation, because their 2010 increase already incorporated higher costs for preparing the investment program. Despite additional hiring in health, education, and police and military personnel, wages are also projected to decline because the government plans no nominal wage increase. This would lead to an NOPD of 22.5 percent of NOGDP in 2011 compared to 21.1 percent in 2010. Risks of public spending overruns could develop before the 2011 elections (Table 2).

9. In the medium term, a decline in capital spending is expected to lower the NOPD because the government considers the investment program a temporary measure to address pressing infrastructure bottlenecks. The authorities are working on a mediumterm framework with the following measures:

- $\quad$ Reducing capital spending during $2012-15$ by $6 \frac{1}{2}$ percent of NOGDP.

- $\quad$ Reforming public wage and employment policies. This process will be initiated by civil service audits, scheduled for 2011.

- $\quad$ Rationalizing current spending, in particular, by moderately reducing transfers and subsidies while making space for increasing maintenance costs from the investment program.

With such policies, the NOPD would drop by 14 percent of NOGDP by 2015 (see the authorities' scenario in the text table). The sustainable NOPD ( $71 \frac{1}{2}$ percent of NOGDP) will

\footnotetext{
${ }^{1}$ For a detailed analysis of the compilation of the sustainable NOPD, based on a permanent income hypothesis model, see D. Leigh and J. P. Olters (2006) "Natural resource depletion, habit formation, and sustainable fiscal policy. Lessons from Gabon,” IMF Working Paper No. 06/193.
} 
be reached by 2019 , assuming the government continues the adjustment at the same pace as during 2012-15 on average (Box 1).

10. The fiscal stance has important implications for domestic stability. ${ }^{2}$ Despite large swings in fiscal policy, the real effective exchange rate has remained broadly stable over the last 15 years. As domestic production is limited, swings in fiscal policy tend to lead to an increase in imports rather than domestic demand. Thus, the strong fiscal expansion in 2010 is projected to depress the current account surplus to levels well below the pre-crisis peak.

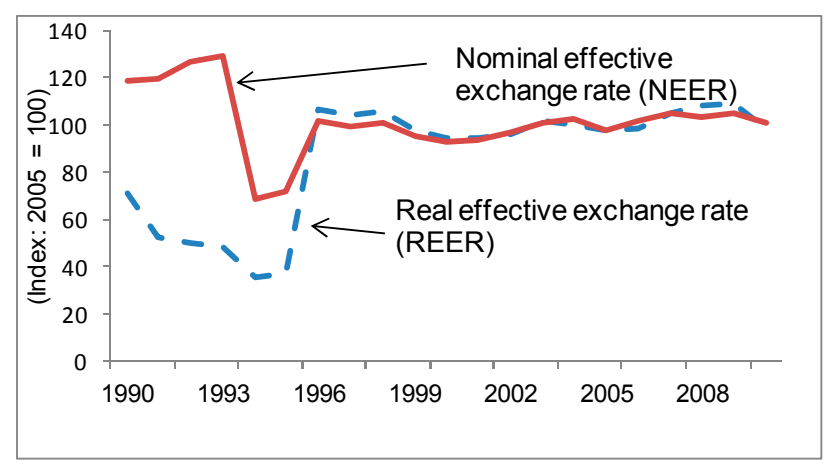

\section{Staff's views}

\section{Medium-term fiscal consolidation is vital to ensuring fiscal sustainability and} external competitiveness as oil production dwindles over time. Public investment plans should be embedded in a realistic multiyear investment plan and the related annual budgets cast within a medium-term fiscal framework consistent with fiscal sustainability and external competitiveness. Given Gabon's vulnerability to shocks and capacity constraints, risk analysis of investment projects and fiscal plans need to be enhanced. With high dependence on commodity exports (Table 5), fiscal policies should be particularly prudent to ensure adequate buffers against risks from changes in commodity prices. The government should consider not further accelerating capital spending in 2011. While the current debt-to-GDP ratio appears moderate, a fall in oil prices could significantly worsen the debt position, as shown in the debt sustainability analysis (Table 6, Appendix).

12. It would be prudent therefore to consolidate the fiscal position faster than under current policies. Staff identified measures that would achieve an additional adjustment of the NOPD of $6 \frac{1}{2}$ percentage points of NOGDP by 2015, consistent with a sustainable longterm fiscal path. As illustrated by the staff's adjustment scenario (Text Table), this adjustment can be achieved by the following key measures:

\footnotetext{
${ }^{2}$ In line with the IMF's surveillance decision, external sustainability is assessed only at the currency union level while analysis at the country level focuses on competitiveness and domestic stability.
} 
- Eliminating unproductive capital spending and anchoring the government's ambitious investment plan in a credible medium-term fiscal framework. By 2015, capital spending should be brought back to historical levels.

- Bringing the wage bill down to sustainable levels by pursuing wage and employment reforms. Staff supports the authorities' plan to cut annual hiring by half after 2011 .

- Allowing the fuel price adjustment mechanism to operate in 2011. This would help contain fiscal risks from changes in oil prices. Subsidies not well targeted to benefit the poor should be abolished by 2012 .

- Reducing tax exemptions gradually. Given the authorities' favorable approach to tax exemptions for export processing zones (EPZ), they could consider reducing non-EPZ related exemptions in the VAT and income tax in line with the IMF's Fiscal Affairs Department (FAD) recommendations.

- Implementing tax administration reforms that have already been initiated, in line with advice provided by (FAD).

Text Table: Comparison of the Authorities' and Staff's Adjustment Scenarios, 2010-2015

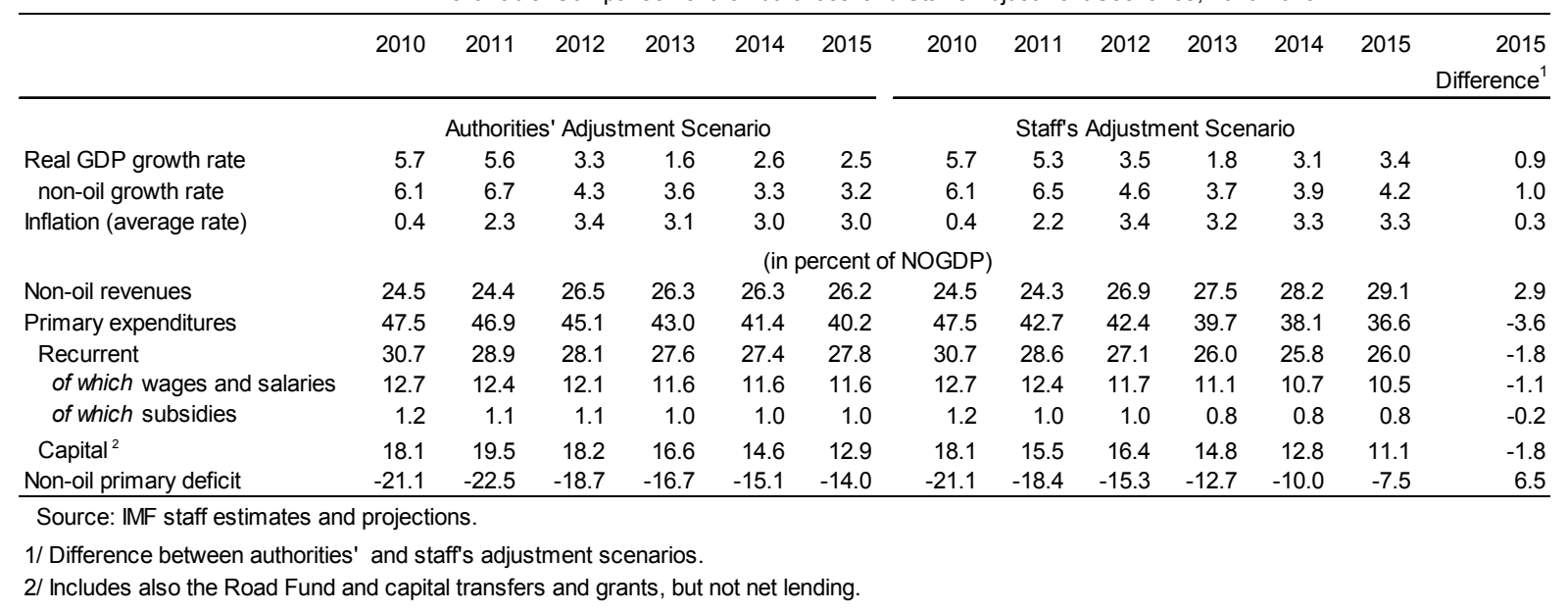

\section{Authorities' views}

\section{The authorities agreed with staff's assessment of fiscal sustainability and}

external competitiveness. They explained the main principles of a medium-term framework, currently being prepared, to bring the deficit down to a sustainable level by reducing capital spending gradually in the medium term, pursuing wage and employment reforms, and rationalizing expenditures on goods and services as well as transfers and subsidies. The medium-term budgetary framework to be put in place will also take into account fiscal risks.

\section{Ongoing tax and customs administration reforms should strengthen non-oil} revenues, including through better control of tax exemptions. While exemptions related 
to EPZ would be phased out according to the law, the authorities pointed out the overall positive impact of EPZ on growth and eventually on fiscal revenue.

\section{Public Financial Management Reform}

\section{The authorities have embarked on major reforms of public financial}

management (PFM), including the introduction of program budgeting and modern principles of financial management. They also are setting up a Caisse de Relance ${ }^{3}$ to carry funds for capital projects over into the next budget year. Regarding managing oil wealth, they have decided to establish a national oil company and to convert the Fund for Future Generations to a Strategic Sovereign Fund (SSF), which will take equity stakes in foreign and domestic companies of strategic importance to Gabon. Because the laws establishing these new funds currently are being drafted, it is not clear whether they will be held at the regional central bank or outside, which would weaken the central bank's international reserves.

\section{Staff's views}

\section{PFM needs to be further improved to enhance the quality of spending and free} resources for growth-enhancing spending and social outlays. In line with FAD's technical assistance recommendations, staff emphasized that the government's objective of carrying over funding for investment projects into the next fiscal year could be achieved without a Caisse de Relance, which will undermine budget execution, cash management, and accountability. There is a substantial risk that governance and accountability will suffer by the establishment of new funds outside the budget. In addition, liquidity management of the SSF should take into account the fiscal risks arising from fluctuating commodity prices.

\section{Authorities' views}

17. The authorities assured staff that they were taking steps to strengthen PFM. The texts creating the various new institutions are either in the preparatory phase or pending adoption. It is their intention to ensure that these institutions are not of an extrabudgetary nature and that they have strong governance structures.

\footnotetext{
${ }^{3}$ In case investment project implementation is delayed, the Caisse de Relance protects these monies from spending cuts by setting them aside in a separate fund.
} 


\section{Box 1: Real Exchange Rate}

Staff's assessment of Gabon's fiscal sustainability and the real exchange rate is based on two methodologies that take into account the future depletion of oil resources. ${ }^{4}$ Both approaches suggest that the fiscal and external positions are broadly in line with fundamentals as long as the authorities implement their intention to lower public spending and the NOPD as outlined in their adjustment scenario. However, poor export performance and weak structural policies underline the need to improve competitiveness.

In the permanent income hypothesis (PIH) approach, the sustainable NOPD is determined by the amount of savings necessary to smooth consumption between generations. Public spending is set equal to a constant path defined in terms of the expected annuity value of oil wealth and non-oil revenue (the government's "permanent income"). For Gabon, the sustainable NOPD deficit is estimated at around

\begin{tabular}{|c|c|c|c|c|}
\hline \multicolumn{5}{|c|}{ External sustainability analysis, 2015} \\
\hline & \multicolumn{2}{|c|}{$\mathrm{PIH}$} & \multicolumn{2}{|c|}{ Bems/Carvalho } \\
\hline & $\begin{array}{c}\text { Authorities' } \\
\text { scenario }\end{array}$ & $\begin{array}{l}\text { Current } \\
\text { policies }\end{array}$ & $\begin{array}{c}\text { Authorities' } \\
\text { scenario } \\
\end{array}$ & $\begin{array}{l}\text { Current } \\
\text { policies }\end{array}$ \\
\hline Current account norm & \multicolumn{2}{|c|}{7.4} & \multicolumn{2}{|c|}{6.0} \\
\hline Underlying current account & 5.2 & 2.5 & 5.2 & 2.5 \\
\hline Current account elasticity ${ }^{1}$ & 0.5 & 0.5 & 0.5 & 0.5 \\
\hline Overvaluation & 4.4 & 9.8 & 1.6 & 7.0 \\
\hline
\end{tabular}

Source: IMF staff estimates.

1/ Elasticities are based on total exports and imports. With non-oil exports and imports, a five times larger REER change would be needed to close the gap, given the small size of the non-oil sector.

$7 \frac{1}{2}$ percent of NOGDP. The current account consistent with this fiscal target determines the current account norm. If the authorities' adjustment scenario was implemented, the overvaluation would be small and well within margins of error. If the fiscal deficit level was maintained at the 2010 level, the overvaluation would be moderate at close to 10 percent by 2015 .

Using the ES-approach in Bems and Carvalho's (2009) ${ }^{5}$ inter-temporal optimization model gives a current account norm that is somewhat smaller than in the PIH model. Consequently, the degree of overvaluation is lower.

Gabon's export performance suggests there is room for improving competitiveness in the noncommodity sectors. Non-commodity exports growth between 2000 and 2008 has been lagging behind SSA's (3.3 percent compared with 14.2 percent). At the same time, the country's market share in world good exports dropped from 0.03 percent in the 1980 s to 0.01 percent in $2000-06$.

Structural factors have been a constraint to competitiveness. According to the World Bank's 2010 Doing Business indicators, Gabon ranked poorly among other upper-middle-income countries with only Venezuela having lower scores. Among 46 SSA countries, Gabon ranked 27th. Another obstacle to private sector development is the high wage level and a rigid labor market.

${ }^{1}$ The results in both models depend heavily on how oil wealth is distributed between generations. For this exercise, oil wealth is distributed using a constant annuity relative to GDP, which leads to a comparably conservative current account norm.

${ }^{2}$ Bems, Rudolfs and Irineu de Carvalho Filho, "Exchange Rate Assessments: Methodologies for Oil Exporting Countries," IMF Working Paper, No. 09/281. 


\section{B. Accelerating Growth to Prepare for the Post-Oil Era}

\section{Gabon suffers from a small tradable sector, constrained by high wages, low} skilled labor, and a poor infrastructure and business environment, which have lead to non-oil growth rates below those of its peers. To accelerate non-oil growth, the government has embarked on an ambitious investment program. Given Gabon's weak administrative capacity, rapid scaling-up of investment, as planned by the government, has a high risk of compromising spending quality. While poor infrastructure has

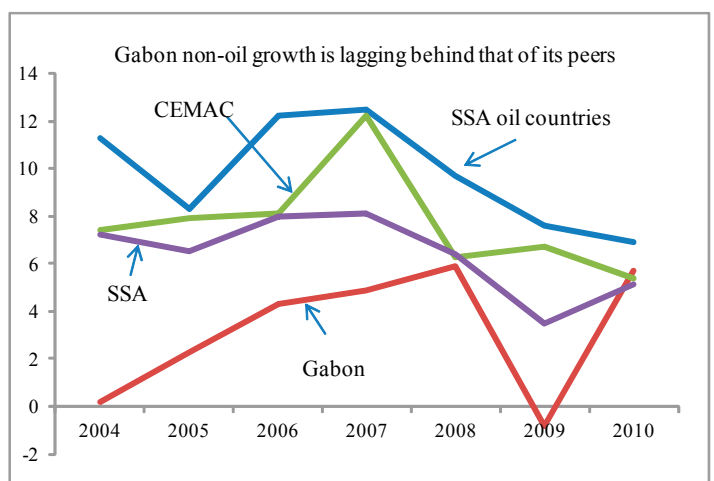
impeded growth, other structural factors, such as a poor business environment and high wages have been the most binding constraints on growth. The poor quality of health and education services, which was also pointed out by civil society representatives, has kept labor productivity low and explains the limited progress in achieving the Millennium Development Goals (Table 7).

\section{Staff's views}

\section{The following reforms are critical to sustaining non-oil growth:}

- $\quad$ Refocus public investment on key infrastructure that will help relieve major supply bottlenecks (e.g., electricity, trade-enabling roads, dam, and ports). The authorities should seek World Bank technical assistance to strengthen the appraisal, selection, and monitoring of investment projects and the budgeting of operation and maintenance costs. Over the medium term, private public partnerships could complement public investment.

- Complement the ambitious infrastructure program by equally important reforms in health and education, which would strengthen labor productivity, generate employment, and alleviate poverty over time.

- Improve the business climate by strengthening governance, enhancing the one-stop window for investors, and streamlining administrative procedures.

- Increase labor market flexibility by reforming labor laws and refraining from government-mandated wage increases in the private sector. Also, public sector wage increases should be moderated to avoid spillover effects on the private sector. 


\section{Authorities' views}

20. To refocus public investment on key infrastructure, five economic development centers have been identified with specific potential in the sectors considered essential for diversifying the economy. The selection of infrastructure to be built will be guided by the need to boost and link the five development centers. These centers therefore will be equipped with high-quality transport, energy, and communications infrastructure.

\section{The authorities have taken several measures to strengthen public investment} management. A national agency for major public works was set up, entrusted with the planning, management, and implementation of large public infrastructure projects. The American engineering corporation, Bechtel, is providing the agency with technical expertise. A service agreement was signed with the World Bank to enhance national capacities in this area.

22. Improvements in health and education are essential to alleviating poverty and to improving labor productivity. The budget envisages hiring new staff for these sectors in 2010 and 2011 and building new classrooms and several clinics.

\section{Reforms to enhance the business environment for private sector promotion} include

- $\quad$ Abolishing burdensome regulations involving lengthy procedures, based on the analysis of the World Bank's Doing Business. A service agreement that will help the government identify the necessary measures to enhance the business environment was signed with the International Finance Corporation (IFC) in November 2010.

- $\quad$ Easing the tax burden on businesses. Tax incentives will continue to play an important role in this strategy. However, the government emphasized that regular assessments of their effectiveness will be built into the strategy.

\section{Reforming the Financial Sector}

\section{Gabon's financial sector has made little headway since the 2006 Central African}

\section{Economic and Monetary Community}

(CEMAC) Financial Stability Assessment

Program (FSAP). Access to financial services is limited, reflecting the underdeveloped payments system. The penetration rate is low at 2 percent, because high operating costs lead banks to concentrate in the most profitable areas. Credit to the private sector is well below the average for sub-Saharan Africa's (SSA's) oil-exporting

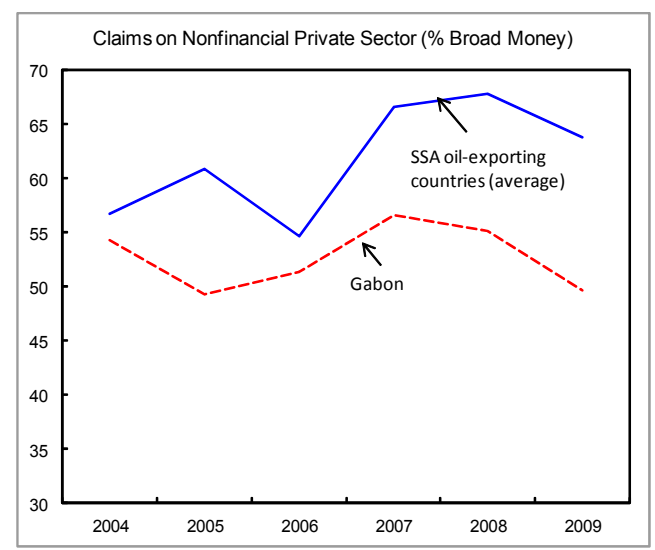


countries. In particular, given the limited role of microfinance institutions, it is difficult for most SMEs to obtain credit (Table 3 and 4).

25. The government still retains a sizeable role in the financial sector. It controls two out of the nine banks and holds significant shares in most of the others. Seeking to facilitate access to financial services and reduce financing costs, the authorities have recently decided to set up a new financial institution, the Caisse des Dépôts et Consignations (CDC).

\section{Staff's views}

26. Staff emphasized the need to improve the institutional environment, rather than creating specialized and government-sponsored financial institutions like the CDC. Institutional reforms should focus on (i) improving the operations of land and commercial registries, (ii) streamlining procedures for recording and enforcing guarantees, and (iii) strengthening creditor rights enforcement by enhancing governance of the relevant courts.

27. To improve SME and private household access to financial services, staff reiterated the need to create credit history centers on SMEs and encouraged the authorities to move ahead quickly with the implementation of the new microfinance strategy.

\section{Authorities' views}

28. Institutional reforms to enhance credit infrastructure are ongoing. These include improved mechanisms and procedures to settle loan contract disputes, streamlined procedures for the realization of guarantees to obtain loans, and creation of a corporate balance sheet centralization system at the central bank that provides commercial banks access to companies' balance sheets.

29. Efforts are also underway to facilitate SME access to financial services. Notably, the authorities intend to subscribe to the capital of the African Guarantee and Economic Cooperation Fund, which guarantees bank loans to SMEs. Work is ongoing to finalize the microfinance development strategy to expand access to credit, while limiting operational and security risks. Finally, reforms are under way to streamline financing instruments through the restructuring of several public agencies currently involved in SME and housing financing.

\section{Other Issues}

30. Other issues were also addressed in the discussions:

- $\quad$ Trade policy. Consistent with its free market trade policy, the government plans to streamline the work of several government agencies involved in export and investment promotion. The establishment of the competition authority, expected to become operational shortly, will ensure that the free play of competition is not hampered by illicit price fixing arrangements, mainly in the retail market. 
- $\quad$ Noncompliance with Article VIII. In 2008, the authorities introduced a tax on wire transfers, which is not consistent with the requirements under Article VIII. They assured staff that they are working to resolve this issue. Because the funds generated by this tax contribute to financing the health insurance fund, reforming this tax is politically sensitive.

- Data quality. While data provision is generally adequate for surveillance, staff analysis was hampered by shortcomings in balance of payments statistics; timeliness of fiscal, monetary, and financial sector data; and lack of high-frequency indicators for economic activity (Informational Annex, Supplement II). With technical assistance from the IMF and other donors, the authorities are continuing efforts to strengthen economic and financial data.

\section{Staff Appraisal}

31. After being hit hard by the global economic crisis, Gabon has recovered quickly. Near-term growth is projected to rise, supported by public investment and a rebound in mining, while inflation would remain subdued. The foremost risk to the economic outlook stems from a significant decline in oil and manganese prices.

32. As oil reserves dwindle over the long term, sustained fiscal consolidation is vital to long-term growth, fiscal sustainability, and external competitiveness. The government's ambitious capital budget should be anchored in a realistic multiyear investment plan and a credible medium-term fiscal strategy to safeguard macroeconomic stability. Annual budgets need to be linked to longer-term policies and to making progress toward fiscal sustainability.

33. Good governance and accountability are critical for ensuring the efficient use of public resources and obtaining the long-term growth dividend from ambitious public investment plans. The new emphasis on PFM reforms is rightly placed, because better public financial management is needed to improve the quality of spending and release resources for growth-enhancing spending and social outlays. Accelerating reforms to refocus public investment on key infrastructure and social projects and to strengthen the appraisal, selection, and monitoring of projects is crucial for ensuring that oil resources are not squandered. Stringent mechanisms should also be in place to ensure transparency and accountability in the management of oil wealth.

34. The real effective exchange rate appears to be broadly in line with fundamentals if the authorities implement their intention to lower public investment spending and the NOPD after 2011. If the NOPD is maintained at the 2010 level, the real exchange rate would appear overvalued. Looking at the performance of the non-oil sector, there is evidence that structural factors are a significant constraint on external competitiveness. 
35. Competiveness-enhancing reforms should be accelerated to promote and diversify private sector non-oil growth. The priorities are to improve the business climate, build basic infrastructure and enhance health and education services.

36. Limited access to financial services is a severe obstacle to private sector development. Priority should be given to improving the institutional and regulatory environment, in particular for SMEs.

37. The data provided to the Fund are generally adequate for surveillance. However, improvements are needed in balance of payments statistics and timeliness of fiscal, monetary, and financial sector data.

38. Gabon maintains a tax on wire transfers, which is inconsistent with its obligations under Article VIII. Staff does not recommend approval.

39. It is expected that the next Article IV consultation will be held on the standard 12-month cycle. 
Table 1: Gabon: Selected Economic Indicators, 2008-15

\begin{tabular}{|c|c|c|c|c|c|c|c|c|}
\hline & 2008 & 2009 & 2010 & 2011 & 2012 & 2013 & 2014 & 2015 \\
\hline & \multicolumn{2}{|c|}{ Est. } & \multicolumn{6}{|c|}{ Proj. } \\
\hline & \multicolumn{8}{|c|}{ (Annual percent change, unless otherwise indicated) } \\
\hline \multicolumn{9}{|l|}{ Real sector } \\
\hline GDP at constant prices & 2.3 & -1.4 & 5.7 & 5.6 & 3.3 & 1.6 & 2.6 & 2.5 \\
\hline Oil & -1.4 & -4.5 & 4.1 & 1.5 & -0.8 & -6.1 & -0.6 & -0.7 \\
\hline Non-oil & 3.4 & -0.5 & 6.1 & 6.7 & 4.3 & 3.6 & 3.3 & 3.2 \\
\hline GDP deflator & 14.7 & -19.4 & 18.0 & 4.8 & 2.8 & 1.2 & 1.0 & 0.8 \\
\hline Oil & 22.8 & -29.8 & 35.4 & 6.1 & 2.7 & 0.8 & 0.9 & 0.0 \\
\hline \multicolumn{9}{|l|}{ Consumer prices } \\
\hline Yearly average & 5.3 & 2.1 & 0.4 & 2.3 & 3.4 & 3.1 & 3.0 & 3.0 \\
\hline End of period & 5.6 & 0.8 & 0.4 & 3.5 & 3.2 & 3.1 & 3.0 & 3.0 \\
\hline \multicolumn{9}{|l|}{ External sector } \\
\hline Exports, f.o.b. (US\$) & 34.4 & -36.7 & 25.5 & 8.0 & 2.0 & -6.2 & 0.2 & 0.9 \\
\hline Imports, f.o.b. (US\$) & 7.7 & 3.3 & 21.9 & 1.7 & 3.9 & 3.9 & 0.2 & 3.6 \\
\hline Terms of trade (deterioration $=-$ ) & 13.4 & -22.6 & 11.0 & 1.6 & 1.8 & 0.4 & 0.4 & 1.0 \\
\hline \multicolumn{9}{|l|}{ Central government finance } \\
\hline Total revenue & 27.0 & -18.9 & 17.3 & 12.1 & 8.6 & 1.1 & 3.0 & 2.8 \\
\hline Oil revenue & 42.0 & -38.5 & 40.0 & 11.6 & 1.6 & -5.9 & 0.3 & 0.8 \\
\hline \multirow[t]{2}{*}{ Total expenditure } & 13.7 & -1.4 & 23.3 & 12.6 & 4.8 & 5.3 & 0.9 & 1.8 \\
\hline & \multicolumn{8}{|c|}{ (Percent of GDP, unless otherwise indicated) } \\
\hline Non-oil primary balance (percent of non-oil GDP) & -14.8 & -13.9 & -21.1 & -22.5 & -18.7 & -16.7 & -15.1 & -14.0 \\
\hline Overall balance (commitment basis) & 11.4 & 6.5 & 4.8 & 5.0 & 6.1 & 5.0 & 5.5 & 5.8 \\
\hline Net domestic financing & 3.7 & -1.4 & -0.3 & -4.9 & -4.5 & -3.5 & -4.4 & -4.6 \\
\hline Net external financing & -13.1 & -1.1 & -0.1 & 0.1 & -1.5 & -1.4 & -1.1 & -1.1 \\
\hline \multirow[t]{2}{*}{ External public debt (including to the Fund) } & 15.6 & 18.8 & 15.7 & 14.3 & 13.1 & 12.6 & 12.2 & 11.7 \\
\hline & \multicolumn{8}{|c|}{ (Percent Change, unless otherwise indicated) } \\
\hline \multicolumn{9}{|l|}{ Money and credit } \\
\hline Credit to the economy & 6.0 & -7.9 & 6.0 & 10.8 & 10.3 & 14.3 & 10.8 & 9.9 \\
\hline Broad money & 8.8 & 2.2 & 8.3 & 9.2 & 9.5 & 10.5 & 6.1 & 5.0 \\
\hline \multirow[t]{2}{*}{ Velocity ratio of NOGDP over broad money } & 2.8 & 2.5 & 2.6 & 2.7 & 2.7 & 2.7 & 2.7 & 2.7 \\
\hline & \multicolumn{8}{|c|}{ (Percent of GDP, unless otherwise indicated) } \\
\hline Gross national savings & 45.3 & 34.1 & 36.8 & 38.9 & 38.1 & 34.8 & 33.7 & 32.4 \\
\hline Gross fixed investment & 22.0 & 26.2 & 26.3 & 27.3 & 27.8 & 28.6 & 27.7 & 27.3 \\
\hline \multirow[t]{2}{*}{ Current account balance } & 23.3 & 7.9 & 10.5 & 11.6 & 10.2 & 6.2 & 6.0 & 5.2 \\
\hline & \multicolumn{8}{|c|}{ (CFA francs billion, unless otherwise indicated) } \\
\hline \multicolumn{9}{|l|}{ Memorandum items } \\
\hline Nominal GDP & 6,508 & 5,170 & 6,444 & 7,127 & 7,569 & 7,786 & 8,072 & 8,339 \\
\hline Nominal non-oil GDP & 3,155 & 2,924 & 3,279 & 3,720 & 4,073 & 4,499 & 4,774 & 5,012 \\
\hline
\end{tabular}

Sources: Gabonese authorities and IMF staff estimates and projections. 
Table 2. Gabon: Central Government Accounts, 2008-12

\begin{tabular}{|c|c|c|c|c|c|c|c|}
\hline & \multirow[t]{2}{*}{2008} & \multirow[t]{2}{*}{2009} & \multicolumn{2}{|c|}{2010} & \multicolumn{2}{|c|}{2011} & \multirow{2}{*}{$\begin{array}{l}2012 \\
\text { Proj. }\end{array}$} \\
\hline & & & Suppl. & Proj. & Budget & Proj. & \\
\hline & \multicolumn{7}{|c|}{ (Percent of non-oil GDP) } \\
\hline Total revenue and grants & 65.9 & 57.6 & 56.6 & 60.3 & 59.6 & 59.6 & 59.1 \\
\hline Revenue & 65.9 & 57.6 & 56.0 & 60.3 & 59.6 & 59.6 & 59.1 \\
\hline Oil revenue & 43.2 & 28.6 & 31.5 & 35.7 & 35.1 & 35.1 & 32.6 \\
\hline Non-oil revenue & 22.7 & 29.0 & 24.5 & 24.5 & 24.5 & 24.4 & 26.5 \\
\hline Tax revenue & 21.5 & 27.3 & 23.5 & 23.4 & 23.2 & 23.2 & 25.2 \\
\hline Taxes on income, profits, and capital gains & 7.4 & 11.1 & 7.1 & 7.1 & 7.9 & 7.9 & 9.2 \\
\hline Domestic taxes on goods and services & 4.1 & 4.8 & 4.5 & 4.5 & 4.2 & 4.2 & 4.6 \\
\hline Taxes on international trade and transactions & 8.8 & 9.5 & 10.9 & 10.9 & 10.3 & 10.3 & 10.3 \\
\hline Other non-oil taxes & 1.2 & 1.8 & 0.9 & 0.8 & 0.9 & 0.8 & 1.1 \\
\hline Non-tax revenue & 1.2 & 1.7 & 1.1 & 1.2 & 1.2 & 1.2 & 1.3 \\
\hline Grants & 0.0 & 0.0 & 0.0 & 0.0 & 0.0 & 0.0 & 0.0 \\
\hline Total expenditure and net lending & 42.3 & 46.1 & 60.9 & 50.8 & 48.9 & 50.0 & 47.8 \\
\hline Current expenditure & 28.8 & 31.3 & 30.7 & 30.7 & 28.8 & 28.9 & 28.1 \\
\hline Wages and salaries & 10.3 & 13.0 & 13.0 & 12.7 & 12.4 & 12.4 & 12.1 \\
\hline Goods and services & 6.6 & 7.4 & 6.9 & 7.7 & 6.4 & 6.5 & 6.5 \\
\hline Interest payments & 3.6 & 2.8 & 3.8 & 3.2 & 3.1 & 3.1 & 2.6 \\
\hline Transfers and subsidies & 8.2 & 8.1 & 7.1 & 7.1 & 6.9 & 6.9 & 6.9 \\
\hline Capital expenditure $^{2}$ & 12.9 & 13.1 & 28.1 & 18.1 & 19.5 & 19.5 & 18.2 \\
\hline Domestically financed & 7.7 & 7.2 & 18.9 & 10.6 & 14.4 & 14.4 & 14.7 \\
\hline Overall balance (commitment basis) & 23.5 & 11.5 & -4.9 & 9.5 & 10.7 & 9.6 & 11.3 \\
\hline Total financing & -23.5 & -11.5 & 4.9 & -9.5 & -10.7 & -9.6 & -11.3 \\
\hline Change in arrears & -4.2 & -7.2 & -0.6 & -8.7 & 0.0 & -0.3 & -0.1 \\
\hline Foreign borrowing (net) & -27.0 & -1.9 & 3.6 & -0.2 & 0.2 & 0.2 & -2.9 \\
\hline Drawings & 1.7 & 3.4 & 8.0 & 4.6 & 4.0 & 4.0 & 2.5 \\
\hline Amortization & -32.9 & -5.4 & -4.3 & -4.8 & -3.9 & -3.9 & -5.3 \\
\hline Exceptional financing & 4.2 & 0.1 & 0.0 & 0.0 & 0.0 & 0.0 & 0.0 \\
\hline Domestic borrowing (net) & 7.6 & -2.4 & 1.9 & -0.6 & -10.9 & -9.5 & -8.3 \\
\hline Banking system & 8.7 & 1.3 & 6.0 & -3.4 & -8.0 & -6.6 & -7.4 \\
\hline \multirow[t]{2}{*}{ Non-bank sector } & -1.1 & -3.7 & -4.1 & 2.8 & -2.9 & -2.9 & -0.8 \\
\hline & \multicolumn{7}{|c|}{ (Billion of CFA francs, unless otherwise indicated) } \\
\hline Total revenue and grants & 2,078 & 1,685 & 1,837 & 1,976 & 2,216 & 2,216 & 2,406 \\
\hline Total expenditure and net lending & 1,336 & 1,348 & 1,996 & 1,664 & 1,817 & 1,860 & 1,946 \\
\hline Overall balance & 742 & 338 & -159 & 312 & 398 & 355 & 460 \\
\hline \multicolumn{8}{|l|}{ Memorandum items: } \\
\hline Overall balance (percent of GDP) & 11.4 & 6.5 & -0.1 & 4.8 & 0.2 & 5.0 & 6.1 \\
\hline Non-oil primary balance excluding capital transfers (NOPD) & -467 & -407 & $-1,063$ & -692 & -792 & -837 & -760 \\
\hline as percent of non-oil GDP & -14.8 & -13.9 & -32.4 & -21.1 & -21.3 & -22.5 & -18.7 \\
\hline Non-oil GDP at market prices & 3,155 & 2,924 & $3,279^{\prime \prime}$ & 3,279 & 3,720 & 3,720 & 4,073 \\
\hline
\end{tabular}

Sources: Gabonese authorities and IMF staff estimates and projections.

${ }^{1}$ Includes equity participations on behalf of the strategic wealth fund "Fonds Gabonais d'Investissement Souverain."

${ }^{2}$ Includes Road Fund (FER) allocations, special funds, capital grants, and capital transfers. 
Table 3. Gabon: Monetary Survey, 2008-12

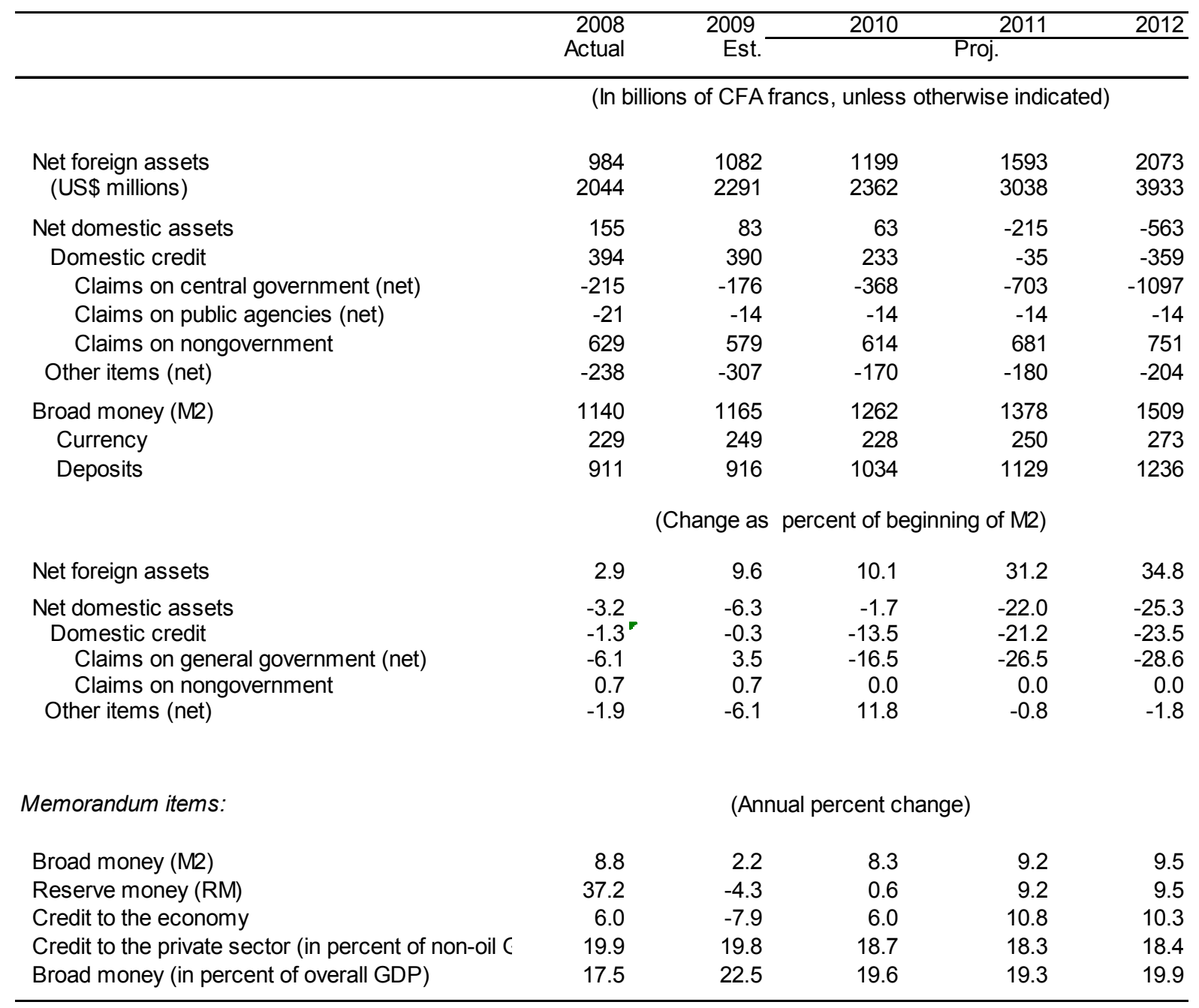

Sources: Gabonese authorities and IMF staff estimates and projections. 
Table 4. Gabon: Financial Soundness Indicators for the Banking Sector, 2003-10

\begin{tabular}{|c|c|c|c|c|c|c|c|c|}
\hline & 2003 & 2004 & 2005 & 2006 & 2007 & 2008 & 2009 & $2010^{1}$ \\
\hline \multicolumn{9}{|l|}{ Capital } \\
\hline Regulatory capital to risk-weighted assets & 19.9 & 22.3 & 19.8 & 17.8 & 14.3 & 19.4 & 24.0 & 22.6 \\
\hline Capital to total assets & 13.1 & 13.2 & 11.1 & 10.2 & 7.0 & 10.7 & 16.2 & 11.3 \\
\hline \multicolumn{9}{|l|}{ Asset quality } \\
\hline Bank nonperforming loans to total loans & 13.9 & 16.0 & 14.1 & 10.7 & 7.6 & 8.5 & 7.2 & 9.9 \\
\hline Bank provisions to nonperforming loans & 53.9 & 53.6 & 55.5 & 57.4 & 59.8 & 61.4 & 71.0 & 56.8 \\
\hline \multicolumn{9}{|l|}{ Earnings and profitability } \\
\hline Return on assets & 0.7 & 2.8 & 2.6 & 2.5 & 2.7 & 1.8 & 2.8 & $\ldots$ \\
\hline Return on equity & 5.7 & 21.3 & 21.1 & 23.5 & 32.3 & 20.8 & 17.2 & $\ldots$ \\
\hline \multicolumn{9}{|l|}{ Liquidity } \\
\hline Liquid assets to short-term liabilities & 33.0 & 55.7 & 60.1 & 57.9 & 107.0 & 52.4 & 62.2 & 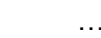 \\
\hline
\end{tabular}

Sources: BEAC and COBAC, and staff estimates using definitions from IMF's "Compilation Guide on Financial Soundness Indicators."

${ }^{1}$ The 2010 data for "capital ratios" were updated in June and those for "asset quality" in August.

Note: $\ldots=$ not available. 
Table 5. Gabon: Balance of Payments, 2008-15

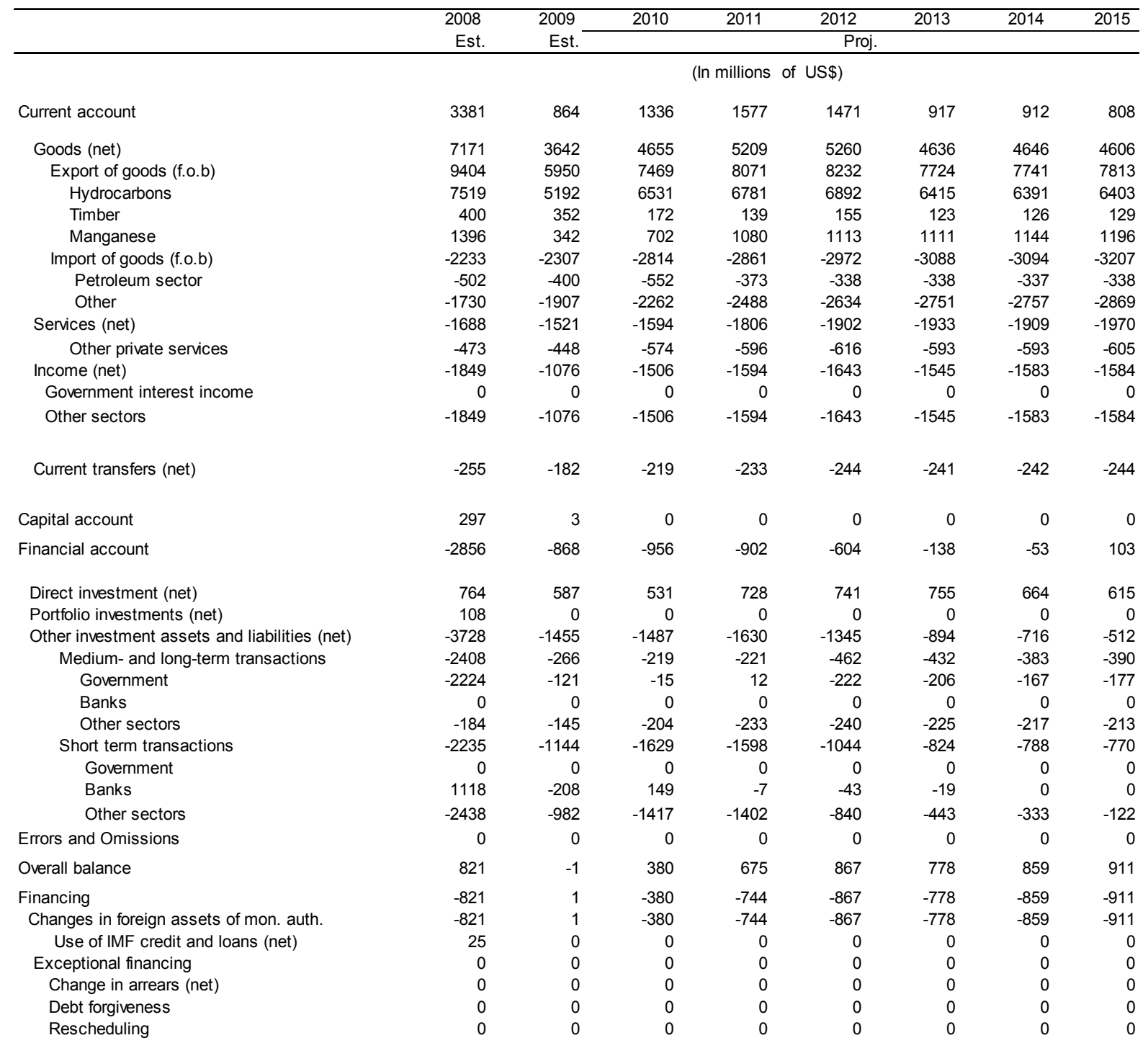

Memorandum items:

(In percent of GDP)

\begin{tabular}{|c|c|c|c|c|c|c|c|c|}
\hline Current account & 23.3 & 7.9 & 10.5 & 11.6 & 10.2 & 6.2 & 6.0 & 5.2 \\
\hline Oil & 32.9 & 30.8 & 31.1 & 31.7 & 30.6 & 27.8 & 26.6 & 26.0 \\
\hline Non-oil & -9.6 & -22.9 & -20.5 & -20.1 & -20.4 & -21.5 & -20.6 & -20.8 \\
\hline Capital and financial accounts & -17.6 & -7.9 & -7.5 & -6.6 & -4.2 & -0.9 & -0.3 & 0.7 \\
\hline Overall balance & 5.7 & 0.0 & 3.0 & 5.0 & 6.0 & 5.3 & 5.7 & 5.8 \\
\hline & \multicolumn{8}{|c|}{ (In billions of US\$, unless otherwise indicated) } \\
\hline Gross official reserves imputed to Gabon & 2.9 & 2.0 & 2.1 & 2.9 & 4.2 & 5.8 & 7.3 & 8 \\
\hline CEMAC gross official reserves & 14.8 & 13.6 & 17.1 & 22.2 & 27.9 & 33.9 & 39.7 & 45.0 \\
\hline (months of CEMAC imports of GNFS) & 6.6 & 5.9 & 7.0 & 9.1 & 11.3 & 13.5 & 15.6 & 15 \\
\hline (percent of broad money) & 117.6 & 106.4 & 132.6 & 158.8 & 180.6 & 200.3 & 219.5 & 232. \\
\hline
\end{tabular}

Sources: Gabonese authorities and IMF staff estimates and projections. 
Table 6: Gabon: External Debt, 2008-12

\begin{tabular}{|c|c|c|c|c|c|}
\hline & 2008 & 2009 & 2010 & 2011 & 2012 \\
\hline & \multicolumn{2}{|c|}{ Est. } & \multicolumn{3}{|c|}{ Proj. } \\
\hline & \multicolumn{5}{|c|}{ (In millions of US\$, unless otherwise indicated) } \\
\hline \multicolumn{6}{|l|}{ Debt stocks } \\
\hline Total external debt (including IMF) & 2,264 & 2,054 & 1,999 & 1,944 & 1,879 \\
\hline Multilateral & 353 & 280 & 268 & 265 & 288 \\
\hline Bilateral & 947 & 924 & 941 & 914 & 830 \\
\hline Paris Club & 790 & 707 & 635 & 567 & 444 \\
\hline Commercial debt & 964 & 850 & 790 & 765 & 761 \\
\hline International bond & 940 & 850 & 790 & 765 & 761 \\
\hline \multicolumn{6}{|l|}{ Debt service } \\
\hline \multicolumn{6}{|l|}{ Principal } \\
\hline Total (including IMF) & 2,345 & 329 & 314 & 302 & 268 \\
\hline Multilateral & 83 & 63 & 57 & 66 & 53 \\
\hline Bilateral & 2,115 & 174 & 149 & 212 & 192 \\
\hline Paris Club & 2,097 & 138 & 138 & 156 & 176 \\
\hline Commercial debt & 147 & 93 & 107 & 25 & 23 \\
\hline \multicolumn{6}{|l|}{ Interest } \\
\hline Total (Including IMF) & 183 & 136 & 159 & 171 & 172 \\
\hline Multilateral & 18 & 20 & 21 & 47 & 19 \\
\hline Bilateral & 77 & 43 & 82 & 60 & 64 \\
\hline Paris Club & 70 & 38 & 71 & 49 & 52 \\
\hline \multirow[t]{2}{*}{ Commercial debt } & 89 & 73 & 74 & 66 & 66 \\
\hline & \multicolumn{5}{|c|}{ (In percent) } \\
\hline \multicolumn{6}{|l|}{ Memorandum items: } \\
\hline Debt service to exports ratio & 27.0 & 8.1 & 7.3 & 5.8 & 5.3 \\
\hline External public debt to GDP ratio & 15.6 & 18.8 & 15.7 & 14.3 & 13.1 \\
\hline External public debt to exports ratio & 23.4 & 32.4 & 25.6 & 22.9 & 21.7 \\
\hline
\end{tabular}

Sources: Gabonese authorities and IMF staff estimates and projections. 
Table 7. Gabon: Millennium Development Goals, 1990-2008

Indicators

Goal 1: Eradicate extreme poverty and hunger

Employment to population ratio, ages $15+$, total (in percent)

Employment to population ratio, ages $15 / 24$, total (in percent)

Malnutrition prevalence, weight for age (in percent of children under 5)

Goal 2: Achieve universal primary education

Primary completion rate, total (in percent of relevant age group)

Total enrollment, primary (in percent)

Goal 3: Promote gender equality and empower women

Proportion of seats held by women in national parliaments (in percent)

Ratio of female to male primary enrollment (in percent)

Goal 4: Reduce child mortality

Immunization, measles (in percent of children ages 12/23 months)

Mortality rate, infant (per 1,000 live births)

Mortality rate, under-5 (per 1,000 )

Goal 5: Improve maternal health

Births attended by skilled health staff (in percent)

Maternal mortality ratio (modeled estimate, per 100,000 live births)

Goal 6: Combat HIVIAIDS, malaria, and other diseases

Incidence of tuberculosis (per 100,000 people)

Prevalence of HIV, total (in percent of population ages 15-49)

Tuberculosis case detection rate (all forms)

Goal 7: Ensure environmental sustainability

$\mathrm{CO} 2$ emissions (metric tons per capita)

Forest area (in percent of land area)

Improved sanitation facilities (in percent of population with access)

Improved water source (in percent of population with access)

Goal 8: Develop a global partnership for development

Net ODA received per capita (current US\$)

Debt service (PPG and IMF only, in percent of exports, excluding remittances)

Internet users (per 100 people)

Mobile cellular subscriptions (per 100 people)

Telephone lines (per 100 people)

19901995

2000

2005

2008

\begin{tabular}{|c|c|c|c|c|}
\hline 58 & 60 & 59 & 58 & 58 \\
\hline 37 & 40 & 38 & 35 & 33 \\
\hline$\ldots$ & $\ldots$ & 9 & $\ldots$ & $\ldots$ \\
\hline 62 & 68 & 72 & 70 & $\cdots$ \\
\hline$\ldots$ & 92 & 82 & $\ldots$ & $\ldots$ \\
\hline 13 & $\ldots$ & 8 & 9 & 17 \\
\hline 100 & 99 & 100 & 99 & $\ldots$ \\
\hline 76 & 57 & 55 & 55 & 55 \\
\hline 68 & 64 & 61 & 56 & 53 \\
\hline 93 & 87 & 83 & 77 & 71 \\
\hline$\ldots$ & $\ldots$ & 86 & $\ldots$ & \\
\hline 260 & 250 & 260 & 260 & 260 \\
\hline 150 & 150 & 250 & 320 & 450 \\
\hline 0.9 & 3.0 & 5.3 & 6.0 & 5.9 \\
\hline 65 & 68 & 73 & 56 & 69 \\
\hline 7 & 4 & 1 & 1 & 1 \\
\hline 85.1 & 84.9 & 84.7 & 84.5 & 84.4 \\
\hline$\ldots$ & 36 & 36 & 33 & 33 \\
\hline$\ldots$ & 84 & 85 & 86 & 87 \\
\hline 142 & 132 & 9 & 44 & 38 \\
\hline 5 & 15 & 9 & 3 & . \\
\hline 0.0 & 0.0 & 1.2 & 4.9 & 6.2 \\
\hline 0 & 0 & 10 & 54 & 90 \\
\hline 2 & 3 & 3 & 3 & 2 \\
\hline
\end{tabular}

Sources: World Bank, Development Data Group

Note: $\ldots=$ not available. 


\section{Appendix: I Assessing Debt Sustainability}

\section{External debt sustainability}

Debt level and structure. Gabon's external debt amounted to US\$2.1 billion (18.8 percent of GDP) as of end-2009 (Table A1). Bilateral debt accounted for 45 percent while bonds issued in 2007 made up 41 percent. The remaining debt is owed to multilateral institutions.

Baseline scenario. Under the baseline scenario, we assume that the medium-term non-oil primary fiscal deficit would decline from 21.1 percent of NOGDP in 2010 to 14 percent in 2015. Real non-oil GDP growth increases steadily from -0.5 percent in 2009 to about 6.1 percent in 2010 and then declines gradually to 3.2 percent in 2015 . Gabonese interest rates closely follow projected world interest rates. International oil and other commodity prices reflect World Economic Outlook projections through 2015. Under this scenario, the debt-to-GDP ratio would continue to decline to 11.7 percent of GDP by 2015 , reflecting the debt-reducing effects of primary surpluses, economic growth, and low interest payments.

Shocks. The risks to this outlook are substantial. While the impact of changes in interest rates, non-oil growth, and the depreciation shock are benign, the current account shock proxied by the oil price shock would reverse the downward trend of the debt-to-GDP ratio, reaching 37.4 percent by 2015 .

- A permanent increase in the real interest rate of 90 basis points (one half standard deviation from its past distribution) relative to the baseline would lead to an increase of the debt-to-GDP ratio to 13.4 percent (Figure A1, panel 2).

- A permanent decrease of non-oil GDP of around 1 percentage point (one half standard deviation from its past distribution) would increase the debt to 14.8 percent of GDP (Figure A1, panel 3).

- A permanent oil price decrease of around 13 dollars per barrel (one half standard deviation from its past distribution) would lead to a substantial increase in the debtto-GDP ratio to 37 percent (Figure A1, panel 4).

- A combination of the former three shocks (a quarter standard deviation from their past distribution) would lead to an increase in the debt to 24 percent of GDP (Figure A1, panel 5).

- A real deprecation shock of 30 percent would increase the debt-to-GDP ratio by 5 percentage points and stabilize it at around 19 percent by 2015 (Figure A1, panel 6). 
Table A1. Gabon: External Debt Sustainability Framework, 2005/2015

(In percent of GDP, unless otherwise indicated)

\begin{tabular}{|c|c|c|c|c|c|c|c|c|c|c|c|}
\hline & \multicolumn{5}{|c|}{ Actual } & \multicolumn{6}{|c|}{ Projections } \\
\hline & 2005 & 2006 & 2007 & 2008 & 2009 & 2010 & 2011 & 2012 & 2013 & 2014 & 2015 \\
\hline 1 Baseline: External debt & 41.6 & 32.5 & 34.9 & 15.6 & 18.8 & 15.7 & 14.3 & 13.1 & 12.6 & 12.2 & 11.7 \\
\hline 2 Change in external debt & -27.2 & -9.1 & 2.5 & -19.3 & 3.2 & -3.0 & -1.4 & -1.2 & -0.5 & -0.4 & -0.5 \\
\hline 3 Identified external debt-creating flows $(4+8+9)$ & -35.3 & -22.7 & -29.3 & -35.6 & -8.2 & -15.6 & -17.8 & -15.9 & -11.6 & -10.7 & -9.4 \\
\hline 4 Current account deficit, excluding interest payments & -26.0 & -17.3 & -18.6 & -24.5 & -9.1 & -11.8 & -12.9 & -11.4 & -7.4 & -7.0 & -6.0 \\
\hline Deficit in balance of goods and services & -38.5 & -31.4 & -31.5 & -37.7 & -19.4 & -24.1 & -25.0 & -23.4 & -18.4 & -18.1 & -16.9 \\
\hline Exports & 68.3 & 61.8 & 62.1 & 66.6 & 57.9 & 61.6 & 62.4 & 60.4 & 55.8 & 54.3 & 53.4 \\
\hline Imports & 29.8 & 30.4 & 30.6 & 28.9 & 38.5 & 37.5 & 37.4 & 37.0 & 37.4 & 36.2 & 36.4 \\
\hline Net non-debt-creating capital inflows (negative) & 0.1 & -3.5 & -6.7 & -5.3 & -5.4 & -4.2 & -5.4 & -5.2 & -5.1 & -4.4 & -3.9 \\
\hline Automatic debt dynamics ${ }^{1}$ & -9.4 & -1.9 & -4.0 & -5.9 & 6.3 & 0.3 & 0.4 & 0.8 & 1.0 & 0.6 & 0.6 \\
\hline Contribution from nominal interest rate & 2.4 & 2.0 & 1.7 & 1.3 & 1.2 & 1.3 & 1.3 & 1.2 & 1.2 & 1.0 & 0.9 \\
\hline Contribution from real GDP growth & -1.7 & -0.4 & -1.5 & -0.6 & 0.3 & -0.9 & -0.8 & -0.4 & -0.2 & -0.3 & -0.3 \\
\hline Contribution from price and exchange rate changes $^{2}$ & -10.1 & -3.4 & -4.2 & -6.5 & 4.8 & $\cdots$ & $\ldots$ & $\ldots$ & $\ldots$ & $\ldots$ & $\ldots$ \\
\hline 13 Residual, incl. change in gross foreign assets $(2-3)^{3}$ & 8.1 & 13.6 & 31.7 & 16.3 & 11.3 & 12.6 & 16.3 & 14.6 & 11.1 & 10.3 & 8.9 \\
\hline External debt-to-exports ratio (in percent) & 60.9 & 52.5 & 56.2 & 23.4 & 32.4 & 25.6 & 22.9 & 21.7 & 22.5 & 22.4 & 21.9 \\
\hline \multirow{2}{*}{$\begin{array}{l}\text { Gross external financing need (in billions of US dollars) }{ }^{4} \\
\text { in percent of GDP }\end{array}$} & -2.0 & -1.5 & -2.0 & -3.4 & -0.9 & -1.3 & -1.6 & -1.5 & -0.9 & -0.9 & -0.8 \\
\hline & -24.1 & -15.5 & -16.9 & -23.2 & -7.9 & -10.5 & -11.6 & -10.2 & -6.2 & -6.0 & -5.2 \\
\hline \multicolumn{12}{|l|}{ Key Macroeconomic Assumptions Underlying Baseline } \\
\hline Real GDP growth (in percent) & 3.0 & 1.2 & 5.6 & 2.3 & -1.4 & 5.7 & 5.6 & 3.3 & 1.6 & 2.6 & 2.5 \\
\hline GDP deflator in US dollars (change in percent) & 17.2 & 8.9 & 14.8 & 22.8 & -23.6 & 9.7 & 1.4 & 2.3 & 0.7 & 0.5 & 0.3 \\
\hline Nominal external interest rate (in percent) & 4.1 & 5.2 & 6.3 & 4.5 & 6.0 & 7.7 & 8.6 & 8.9 & 9.4 & 7.8 & 7.2 \\
\hline Growth of exports (US dollar terms, in percent) & 25.6 & 5.8 & 21.1 & 34.7 & -34.5 & 23.3 & 8.5 & 2.2 & -5.4 & 0.4 & 1.0 \\
\hline Growth of imports (US dollar terms, in percent) & 6.6 & 19.0 & 21.6 & 18.4 & 0.5 & 12.8 & 6.8 & 4.6 & 3.5 & -0.1 & 3.4 \\
\hline Current account balance, excluding interest payments & 26.0 & 17.3 & 18.6 & 24.5 & 9.1 & 11.8 & 12.9 & 11.4 & 7.4 & 7.0 & 6.0 \\
\hline Net non-debt-creating capital inflows & -0.1 & 3.5 & 6.7 & 5.3 & 5.4 & 4.2 & 5.4 & 5.2 & 5.1 & 4.4 & 3.9 \\
\hline
\end{tabular}

${ }^{1}$ Derived as $[r-g-\rho(1+g)+\varepsilon \alpha(1+r)] /(1+g+\rho+g \rho)$ times previous period debt stock, with $r=$ nominal effective interest rate on external debt; $\rho=$ change in domestic GDP deflator in US $\delta 0 \lambda \lambda \alpha \rho \tau \varepsilon \rho \mu \sigma, g=$ real GDP growth rate, $\varepsilon=$ nominal appreciation (increase in dollar value of domestic currency), and $\alpha=$ share of domestic-currency denominated debt in total external debt. ${ }^{2}$ The contribution from price and exchange rate changes is defined as $[-\rho(1+g)+\varepsilon \alpha(1+r)] /(1+g+\rho+g \rho)$ times previous period debt stock. $\rho$ increases with an appreciating domestic currency $(\varepsilon>0)$ and rising inflation (based on GDP deflator).

${ }^{3}$ For projection, line includes the impact of price and exchange rate changes. The large residuals in 2012-2015 are due to the projected reduction in government savings during that period.

${ }^{4}$ Defined as current account deficit, plus amortization on medium- and long-term debt, plus short-term debt at end of previous period. 
Figure A1. Gabon: External Debt Sustainability: Bound Tests1/

(External debt in percent of GDP)
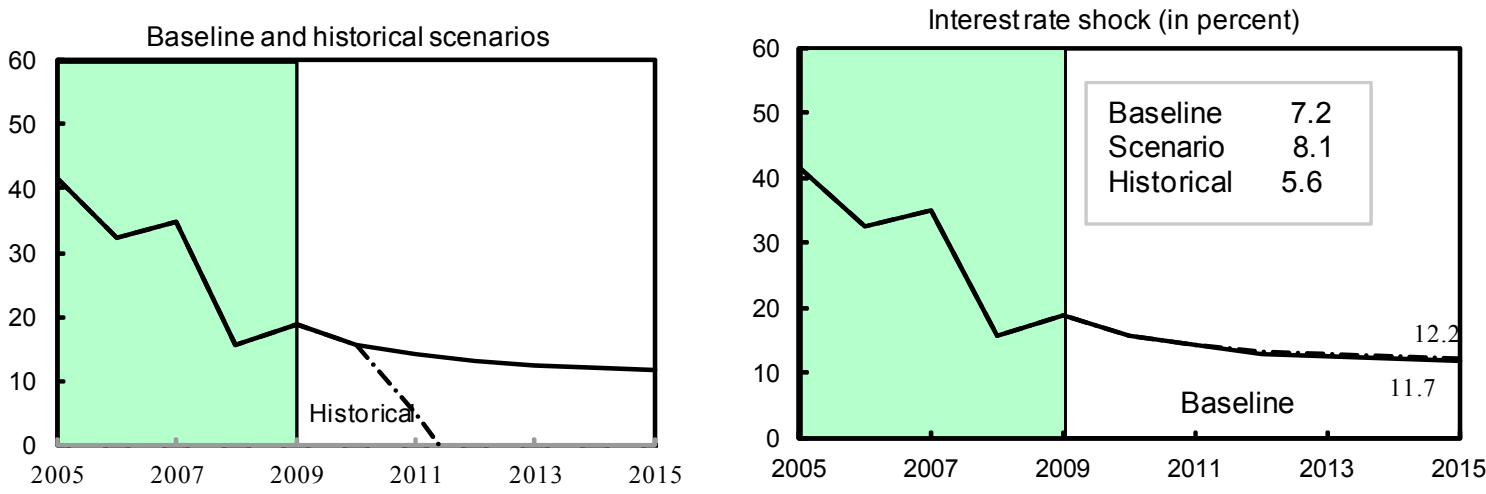

Non oil -growth shock (in percent per year)
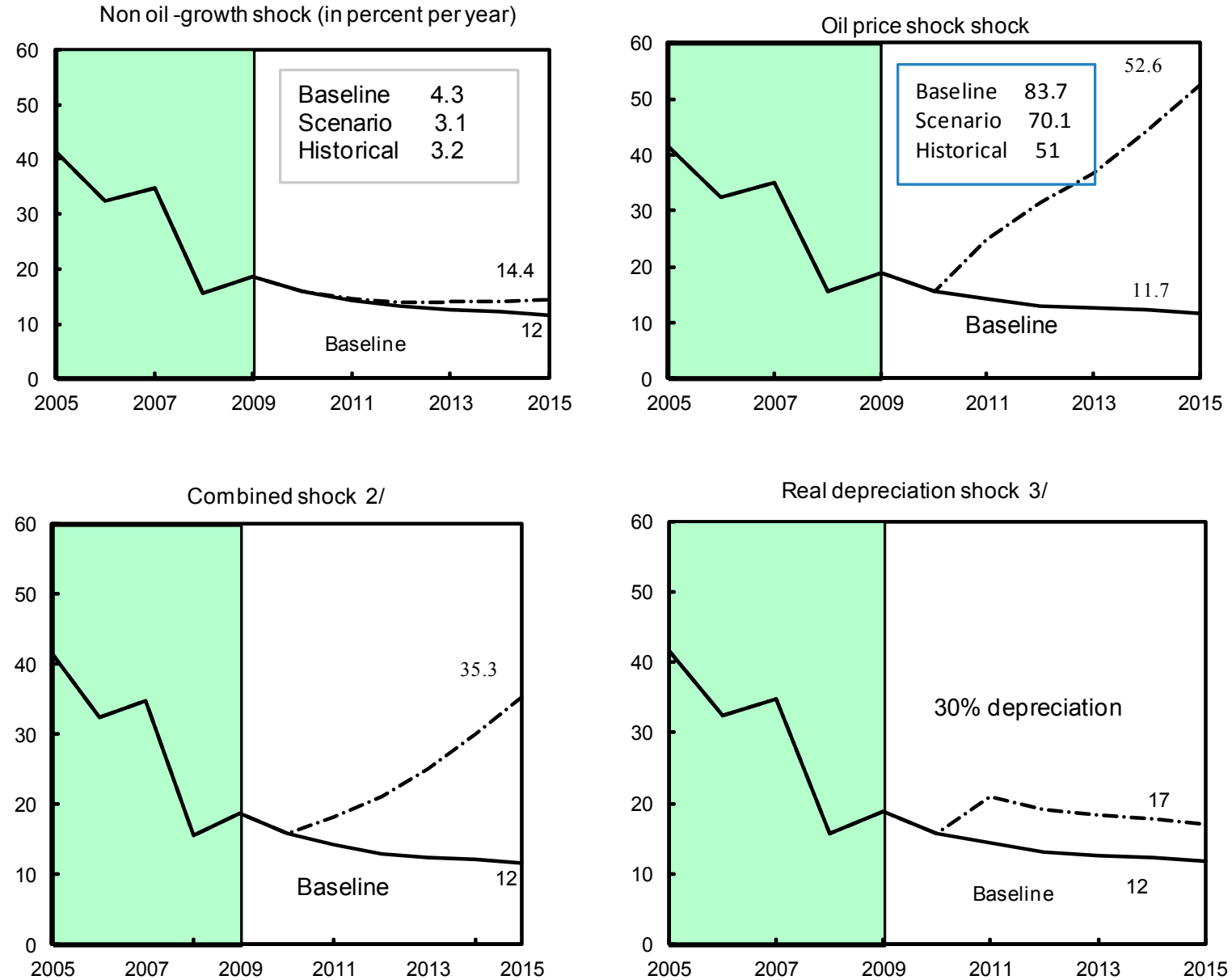

Sources: International Monetary Fund Country desk data and staff estimates.

1 /Shaded areas represent actual data. Individual shocks are permanent one-half standard deviation shocks. Figures in the boxes represent average projections for the respective variables in the baseline and scenario being presented. Ten-year historical average for the variable is also shown. 2/Permanent one quarter standard deviation shocks applied to real interest rate, non-oil growth rate, and the price of oil.

3/One-time real depreciation of 30 percent occurs in 2011. 


\section{Fiscal debt sustainability}

The analysis covers only central government debt, because limited information is available beyond the central government. The findings mirror the external debt sustainability analysis:

The scenarios based on historical averages and the standard stress tests confirm the declining and benign profile of debt for the forecast period. The projections under the historical scenarios differ from the baseline in two respects: a higher average annual GDP growth of 0.6 percent and a lower primary surplus of 4.2 percent. Under the baseline scenario, the public sector debt ratio would decline gradually and stabilize at 14.4 percent of GDP in 2015. Even under standard stress tests, the projected level of public debt would remain well below 40-60 percent of GDP, the range that is often deemed too high for an emerging market. 
Table A2. Gabon: Public Sector Debt Sustainability Framework, 2005-15

(Percent of GDP, unless otherwise indicated)

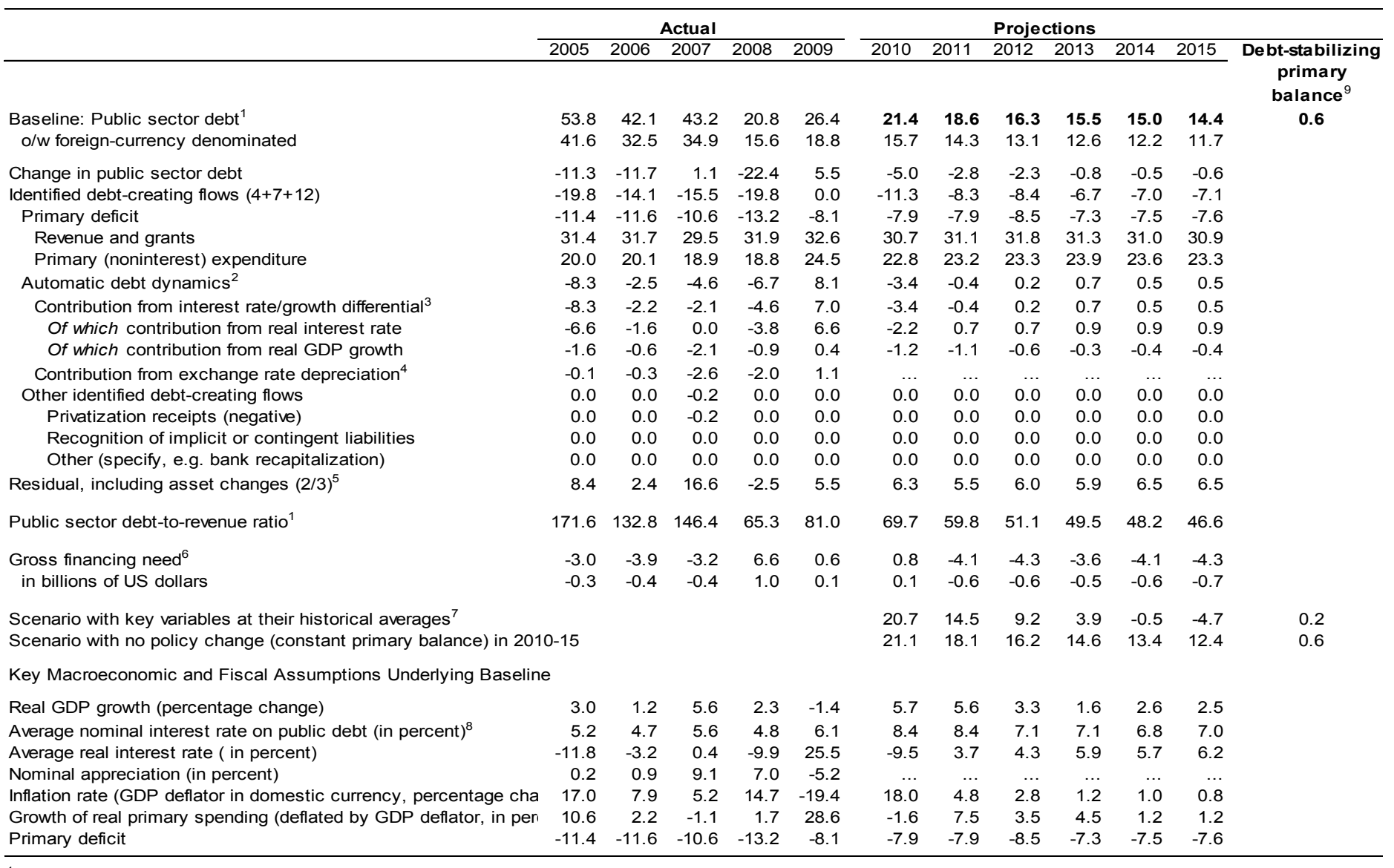

${ }^{1}$ Central government gross debt.

${ }^{2}$ Derived as $[(r-p(1+g)-g+a e(1+r)](1+g+p+g p))$ times previous period debt ratio, with $r=$ interest rate; $p=$ growth rate of GDP deflator; $g=$ real GDP growth rate;

$\mathrm{a}=$ share of foreign-currency denominated debt; and $\mathrm{e}=$ nominal exchange rate depreciation (measured by increase in local currency value of US dollar).

${ }^{3}$ The real interest rate contribution is derived from the denominator in footnote 2 as $r-\pi(1+g)$ and the real growth contribution as $-g$.

${ }^{4}$ The exchange rate contribution is derived from the numerator in footnote 2 as ae(1+r).

${ }^{5}$ For projections, this line includes exchange rate changes.

${ }^{6}$ Defined as public sector deficit, plus amortization of medium and long-term public sector debt, plus short-term debt at end of previous period.

${ }^{7}$ The key variables include real GDP growth; real interest rate; and primary balance in percent of GDP.

${ }^{8}$ Derived as nominal interest expenditure divided by previous period debt stock.

${ }^{9}$ Assumes that key variables (real GDP growth, real interest rate, and other identified debt-creating flows) remain at the level of the last projection year.

Note: $\ldots$ = not available. 
Figure A2. Gabon: Public Debt Sustainability: Bound Tests 1/

(Public debt in percent of GDP)

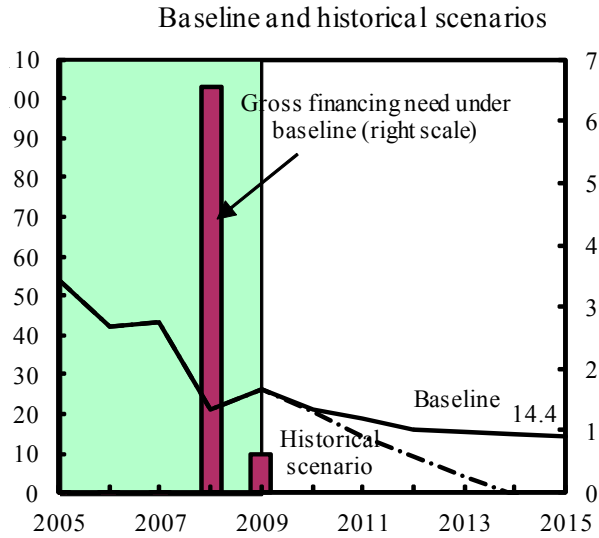

Growth shock (in percent per year)

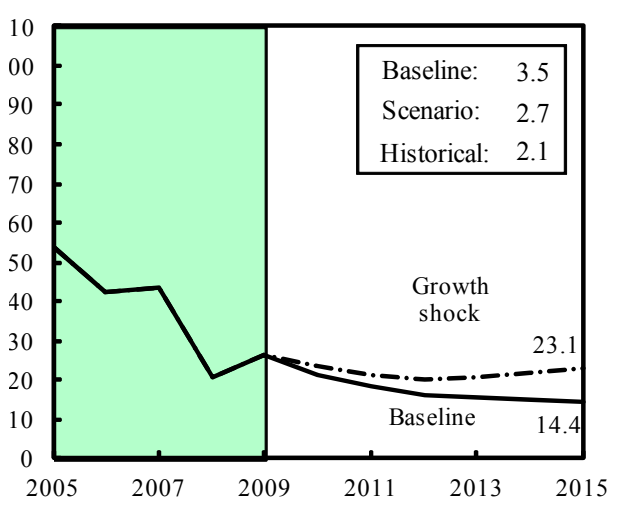

Combined shock 2/

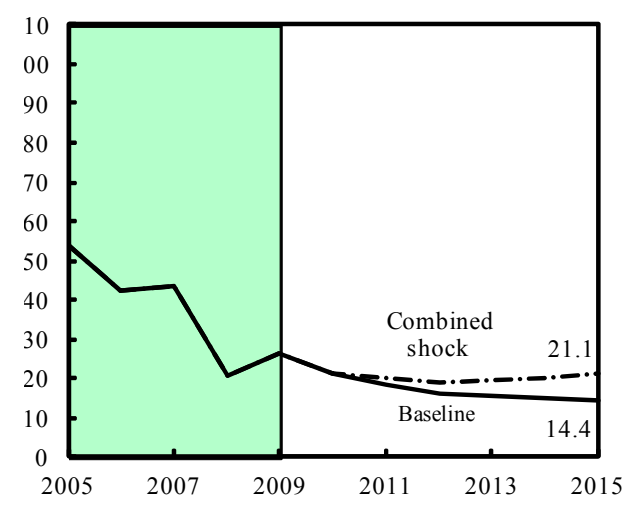

Realinterest rate shock (in percent)

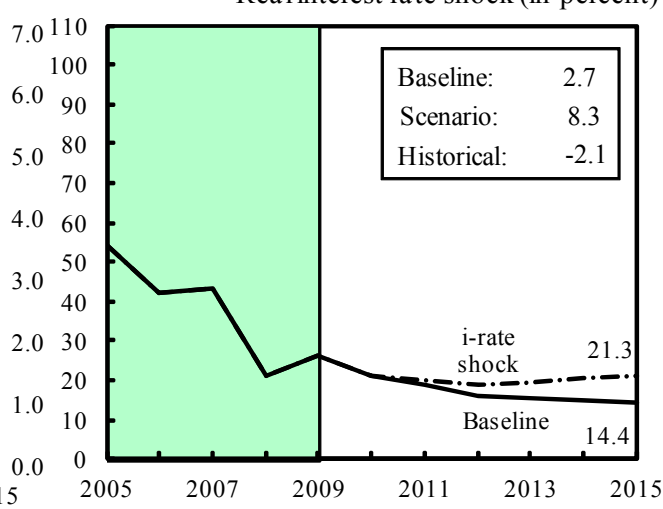

Primary balance shock (in percent of GDP) and no policy change scenario (constant primary balance)

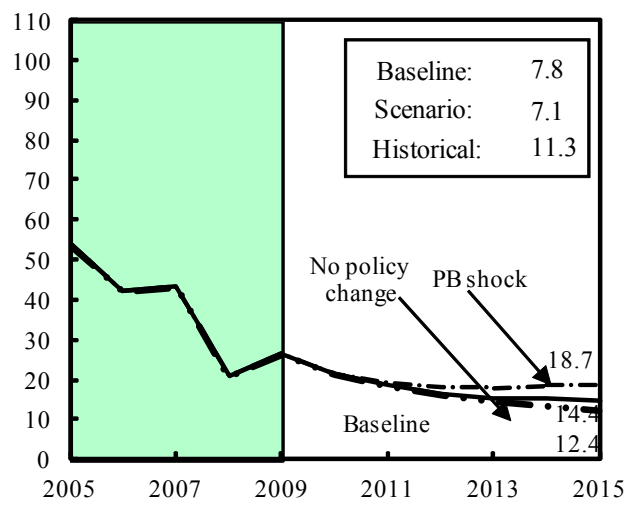

Realdepreciation and contingent liabilities

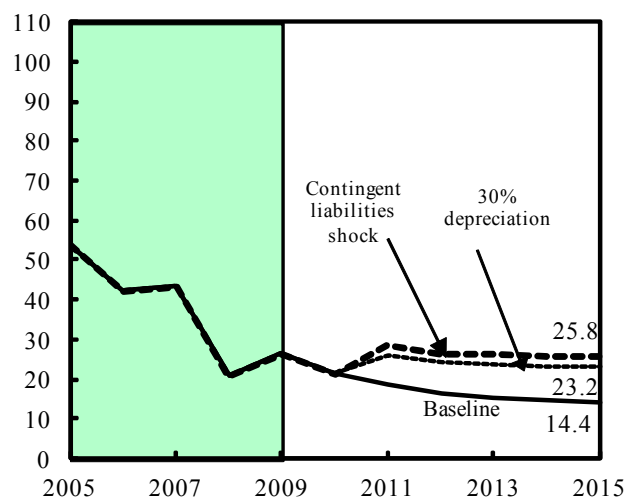

Sources: InternationalMonetary Fund Country desk da ta and sta ff estimates.

1 / Sha ded a rea s represent actual data. Individual shocks a re permanent one-half standard deviation shocks. Figures in the boxes represent average projections for the respective variables in the ba seline and scenario being presented. Seven-year historical average for the variable is also shown. 2 / Perma nent one quarter standard deviation shocks a pplied to real interest rate, growth rate, and primary balance.

3/ One-time real depreciation of 30 percent and 10 percent of GDP shock to contingent liabilities occur in 2011, with real depreciation defined as nominaldepreciation (measured by percentage fall in dollar value of local currency) minus domestic inflation (based on GDP deflator). 
INTERNATIONAL MONETARY FUND

GABON

Staff Report for the 2010 Article IV Consultation

Informational Annex

Prepared by the African Department

(In consultation with other departments)

Approved by Sharmini Coorey and Dhaneshwar Ghura

February 2, 2011

- Relations with the Fund. Gabon has been a member of the International Monetary Fund since 1963. CEMAC member countries accepted the obligations of Article VIII in June/July 1996. The three-year SBA for about US\$118 million expired in May 2010, with only the first three reviews completed. Recurrent fiscal slippages made it difficult to sustain the Fund-supported program.

- Relations with the World Bank. The World Bank signed a \$10 million service agreement with the government which covers sectoral assistance as well as a comprehensive growth analysis and public financial management reform.

- Exchange rate regime: Gabon is a member of the Central African Economic and Monetary Community (CEMAC). The common currency, the CFA franc, is pegged at the fixed rate of 655.957 CFA franc per euro. Gabon's tax on wire transfers constitutes a restriction on the making of payments and transfers for current international transactions subject to approval under Article VIII, Section 2 (a) of the Articles of Agreement.

- Statistical Issues. Gabon has subscribed to the General Data Dissemination System (GDDS). While data are broadly adequate for surveillance purposes, staff analysis was affected by the timeliness and coverage of fiscal data, the poor quality of balance of payments data, and the limited information on labor cost and productivity. 
Annexes

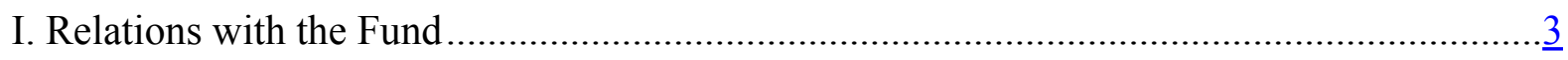

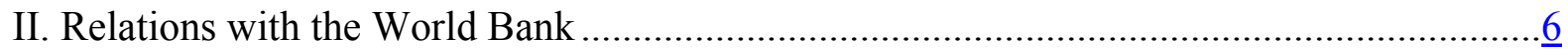

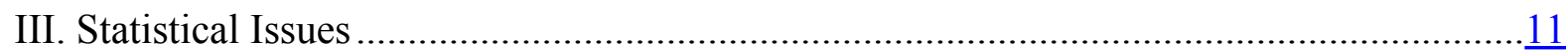




\section{ANNEX I. RELATIONS WITH THE FUND}

(as of October 31, 2010)

I. Membership Status: Joined September 10, 1963

$\underline{\text { Article VIII }}$

II. General Resources Account:

Quota

Fund holdings of currency

Reserve Position

Holdings Exchange Rate

III. SDR Department:

Net cumulative allocation

Holdings
SDR Million

154.30

153.77

0.54

SDR Million

146.72

132.81
\%Quota

100.00

99.66

0.35

IV. Outstanding Purchases and Loans: None

V. Latest Financial Arrangements:

\begin{tabular}{|c|c|c|c|c|}
\hline Type & $\begin{array}{c}\text { Date of } \\
\text { Arrangement }\end{array}$ & $\begin{array}{l}\text { Expiration } \\
\text { Date }\end{array}$ & $\begin{array}{c}\text { Amount } \\
\text { Approved } \\
\text { (SDR Million) } \\
\end{array}$ & $\begin{array}{l}\text { Amount Drawn } \\
\text { (SDR Million) }\end{array}$ \\
\hline Stand-By & May 07, 2007 & May 06, 2010 & 77.15 & 0.00 \\
\hline Stand-By & May 28, 2004 & Jul 31, 2005 & 69.44 & 41.66 \\
\hline Stand-By & Oct 23,2000 & Apr 22, 2002 & 92.58 & 13.22 \\
\hline
\end{tabular}

\section{Projected Payments to Fund (Expectation Basis)}

(SDR Million, based on existing use of resources and present holdings of SDRs):

$\begin{array}{lccccc} & \underline{2010} & \underline{2011} & \underline{\underline{2012}} & \underline{2013} & \underline{2014} \\ \text { Principal } & & & & & \\ \text { Charges/Interest } & 0.11 & 0.06 & 0.06 & 0.06 & 0.06 \\ \quad \text { Total } & \underline{0.11} & \underline{0.06} & \underline{0.06} & \underline{0.06} & \underline{0.06}\end{array}$

VII. Implementation of HIPC Initiative: Not Applicable

VIII. Implementation of Multilateral Debt Relief Initiative (MDRI): Not Applicable

\section{Safeguards Assessments:}

The Bank of the Central African States (BEAC) is the regional central bank of the Central African States. The most recent safeguards assessment of the BEAC was completed on July 6,2009 . The findings of this assessment indicate that implementation of previous 
safeguards recommendations on financial reporting, internal audit, and internal control has been limited, and that the changing risk profile of the BEAC foreign exchange holdings requires further actions to strengthen safeguards at the BEAC. Subsequent to revelation of Paris office fraud, a series of initial measures and longer term safeguard measures were agreed between IMF and BEAC in order to continue with country programs. In December 2009, BEAC adopted an action plan with the aim of reforming its own governance and strengthening key safeguards. While implementation of the 2009 action plan is still in progress, BEAC adopted additional measures to address the weaknesses highlighted by the first special audit.

\section{Exchange Rate Arrangement:}

Gabon is a member of the Central African Economic and Monetary Community (CEMAC). The common currency, the CFA franc, is pegged to the Euro at a fixed rate of CFAF $655.957=€ 1$. Gabon does not have a separate currency.

Like other members of the Central African Economic and Monetary Community (CEMAC), Gabon has accepted the obligations of Article VIII, Section 2.3 and 2.4 of the IMF Articles of Agreement. Gabon levies a tax on all wire transfers, including for the making of payments and transfers for current international transactions, which gives rise to an exchange restriction subject to Fund approval under Article VIII, Section 2(a) of the Fund's Articles of Agreement.

\section{Article IV Consultations:}

(a) Gabon was on a 24-month Article IV consultation cycle while the Stand-By Arrangement was on track and has since been moved to a 12-month cycle.

(b) The Executive Board concluded the last Article IV consultation with Gabon on July 28, 2008.

\section{FSAP Participation:}

A national module for Gabon of the joint IMF/World Bank Financial Sector Assessment Program (FSAP) was completed in 2002 and discussed by the Executive Board in March 2002 (IMF Country Report No. 02/98). A regional FSAP module for the CEMAC was completed in 2006 and discussed by the Executive Board in 2006 (IMF Country Report No. 06/321). 
XIII. Technical Assistance:

A. Central Africa Regional Technical Assistance Center (AFRITAC)

\begin{tabular}{lll}
\hline Area & Focus & Time of \\
& & Delivery \\
\hline Bank supervision & Risk based supervision & Oct. 2010 \\
Public Financial Management & Senior Budget Civil Servants Forum & Sep. 2010 \\
Statistics & Training workshop on ERETES & Jul. 2010 \\
Public Financial Management & Program Budgeting & Apr. 2010 \\
Revenue administration & Small Business Taxation & Mar. 2010 \\
Debt management & Assessment of Phase II technical assistance needs & Dec. 2009 \\
Statistics & Training workshop on ERETES & July. 2009 \\
Public Financial Management & Public Finance Accounting & Oct. 2009 \\
Statistics & Training workshop on ERETES & July. 2009 \\
Public Financial Management & Public Expenditure and Financial Accountability & Apr. 2009 \\
Revenue administration & Combating fiscal fraud & Mar. 2009 \\
Statistics & Use of Enterprise statistics in the national accounts & Feb. 2009 \\
Bank supervision & Applying IAAS for banks & Feb. 2009 \\
Debt management & Savings mobilization in Central African countries & Jan. 2009 \\
Public Financial Management & Internal control and public audit & Oct. 2009 \\
Public financial management & Seminar on Treasury management & Mar. 2008 \\
Economic statistics & National accounts & Mar./Oct. 2008 \\
Revenue administration & Strengthening fiscal administration & Feb. 2008 \\
Revenue administration & Assistance in reform implementation & Feb. 2008 \\
\hline
\end{tabular}

\section{B. Headquarters}

\begin{tabular}{lll}
\hline Department & Purpose & $\begin{array}{l}\text { Time of } \\
\text { Delivery }\end{array}$ \\
\hline FAD & Implementing the new budget system law & Jul. 2010 \\
MCM & Public Debt Management & Jan. 2010 \\
MCM & AFC: Public Debt & Oct. 2010 \\
MCM & Public Debt & Feb. 2010 \\
MCM & Public Debt & Feb. 2009 \\
FAD & Revenue administration—review of reforms and next steps & Sep. 2008 \\
FAD & Seminar on governance and oil and gas contracts & Apr. 2008 \\
MCM & Public debt-handbook elaboration for Gabon & Nov. 2007/ \\
& & Apr. 2008 \\
LEG & Financial Intelligence Unit development & Jun. 2007 \\
FAD & Poverty and social impact analysis of fuel subsidies reform & Jan. 2007 \\
\hline
\end{tabular}

\section{Resident Representative:}

The Fund no longer has a resident representative in Libreville and the IMF office is staffed with a local economist. 


\section{ANNEX II. RELATIONS WITH THE WORLD BANK}

(Updated as of December 9, 2010)

1. Gabon is one of Africa's few IBRD countries. The Bank is working closely with the IMF team to support structural measures, particularly for PFM reform and the development of natural resources.

\section{The Bank Group Strategy and Lending Operations}

The Board of Directors approved the last Gabon Country Assistance Strategy (CAS) on May 24, 2005, and discussed a CAS progress report on January 17, 2008. Discussions are currently underway with the new Government on its priorities for WB support under a new CAS (existing CAS ended June 2009). Possible areas of future cooperation would include energy, telecommunications, and urban development. A US\$75 million road transport operation is scheduled to go to the Board in 2011. Additional new lending operations will be determined based on Government priorities.

2. In August 2010, a three year US\$10 million Reimbursable Technical Assistance Agreement (RTA) was signed to assist the authorities to update their PRSP. The activities focus on public financial management, assessing potential sources of growth in non-oil activities, and an update of the country's poverty profile.

3. As of September 2010, there were five active World Bank financed projects in Gabon, with a commitment value of approximately US\$51 million. Each operation emphasizes improving transparency and efficiency in the use of public resources and improving the environment for participation of the private sector. Projects include:

- Two IBRD-funded operations: a Natural Resources Management Development Policy Loan approved in November 2005 (US\$15 million) and Public Investment Program for Local Infrastructure Development approved in March 2006 (US\$25 million);

- A GEF-funded capacity building project for natural resource management (US\$10 million); and

- Two trust fund operations: an IDF grant for building capacity for managing large infrastructure projects (US\$420,000) and a Forest Carbon Partnership Facility Readiness Grant (US\$200,000).

4. Currently, the IFC has an exposure of US\$32.5 million in oil, gas, electricity, and telecommunications and the World Bank Group's Foreign Investment Advisory Services (FIAS) completed a diagnostic study of the investment climate in late 2004. The IFC is currently negotiating a Service Agreement to improve the business climate. A US\$61 million MIGA guarantee for rehabilitation and modernization of a professional training institute was approved by the Board in May 2005. This project is MIGA's first in the education sector.

\section{IMF-World Bank Collaboration}


IMF and World Bank staff collaborate closely in supporting reforms to foster economic diversification and in coordinating their policy advice to the Gabonese authorities. In view of the ambitious structural measures envisaged under the government's program, successful implementation of the reform program will require substantial technical assistance by the World Bank Group, as spelled out in the three-year service agreement. This includes the areas of business climate improvements, effective and efficient public resources management (including MTEF), poverty reduction policies, nonrenewable resource management, and identification and development of sources of growth in the non-oil sector.

\section{IMF-World Bank Collaboration in Specific Areas}

\section{Areas where there is no direct IMF involvement}

5. The Bank supported completion of the Government's poverty reduction strategy has helped the Government to design its first national statistical development strategy and provides continued support for strengthening statistical capacity and assisting the NSO (National Statistical Office). In summer 2005 the Bank provided financial and technical assistance for household surveys using a Core Welfare Indicators Questionnaire (CWIQ) to update social indicators to be monitored annually. The results of the CWIQ household survey were used in finalizing the GPRSP.

6. The Bank provided support to develop statistical capacity in Gabon through a recipient-executed (Ministry of Plan) statistical capacity building grant from the Statistical Capacity Building Program in the amount of US $\$ 399,850$. Implementation took place from September 2007 to June 2010. The objective of the grant was to support the government in the development of a national strategy for the development of statistics.

7. In the context of the RTA, a poverty study will be carried out as well as analytical work on sources and constraints to growth, economic and export diversification as well as competitiveness.

\section{Areas where the World Bank leads and its analysis guides IMF activity}

8. In November 2005, the Bank Board approved a US\$15 million Natural Resources Management Development Policy Loan (DPL) that covers the forest, environment, fisheries, mining, and oil sectors. This operation aims at improving the efficiency of natural resources management, accelerating poverty reduction, protecting the environment, and reducing the country's oil dependence. In the oil sector, it will support implementation of the EITI. In March 2006, the Board also approved a US\$10 million grant from the Global Environment Facility for Gabon's national parks. It focuses on improving transparency, law enforcement, and removing policy distortions and on helping the authorities implement reforms and empower civil society organizations and local communities to manage natural resources. The project is expected to broaden the number of beneficiaries and raise social and environmental 
standards in the forestry, fishing, and mining sectors, and thus help the government to diversify the economy and reduce its dependence on oil.

9. In June 2004 the Bank completed a US\$5 million Pilot Community Infrastructure Development Project (Learning and Innovation Loan) designed to test new methods for building community-based infrastructure and supporting local contractors. The goal was to improve living conditions in certain poor urban neighborhoods in a sustainable way and with substantial community participation. The project also aimed at building local capacity to undertake a larger program of community-based public works. The initiative was successful, and the Bank on March 14, 2006, approved a US\$25 million loan to (i) increase the access of people living in low-income settlements to basic services; and (ii) sustain the access of local SMEs to civil works and public construction contracts. The project is likely to increase the access of the poor to infrastructure and services, build up SMEs, and improve the quality of public works through increased transparency and efficient procurement and contract management.

10. Possible new projects include a US\$35 million rural electrification project. In electricity, the Government has now expressed interest in collaborating in (i) rural and periurban electrification, (ii) energy efficiency, (iii) institutional capacity building including climate change and (iv) potential structural investments. Options also include the provision of Additional Financing to continue the Local Infrastructure Development Project which closes in December 2011.

11. Within the context of the RTA, sectoral analytical work is planned to be carried out in the areas of agriculture and livestock, the financial sector, fisheries, timber, information and communication technologies and tourism. This analytical work would include technical assistance for each stage of the development of the respective sector, from market analysis and pre-evaluation of investments necessary for the development of the respective industry to technical assistance for the implementation of an action plan.

12. The Bank, through SEGOM (formerly COCPO), has provided support to the Extractive Industries Transparency Initiative (EITI) in Gabon ("how-to" guidance), including initial technical support to assist the Government, industry, and civil society understand the key features of EITI and its benefits in terms of broader governance in the management of natural resources.

\section{Areas of shared responsibility}

13. Strengthening public financial management. The Bank and the Fund will provide coordinated TA on strengthening PFM. Proposed areas of support include:

- Serving as the framework for the PFM TA planned by the two institutions, FAD undertook a comprehensive PFM diagnostic mission in July 2010. This will be followed by more detailed diagnostic work. 
- Expenditure Management: The Bank will provide TA around the development of a Medium-Term Expenditure Framework (MTEF). Support will include work to (i) refine the priority action plan of the PRSP; (ii) strengthen systems for the development of the macroeconomic and budgetary framework and sectoral MTEFs; and (iii) revise the circular for the budget preparation and the assessment of the integrated system in place for programming and monitoring. Work will be closely coordinated with the Fund, which will use the MTEF as an instrument to link fiscal policies with the overall macroeconomic framework.

- Debt Management: Based on a debt management performance assessment (which could commence immediately after a request is received from the government), the Bank will provide TA for the development of a debt strategy, the establishment of a debt office, and the provision of training and support in the implementation of the reform plan.

- Public investment management: Based on a diagnostic of the current system, the Bank proposes TA to support the development of a new framework for public investment management, its implementation, and training.

\section{Strengthening tax policies. The Fund received a request for TA on tax policy} development, including corporate income and natural resource taxation. The Bank's service contract also includes tax policy issues as part of investment advisory services which are a component of its growth diagnostic. To ensure close coordination, the Bank will consult with FAD on all tax policy missions that may be planned. This could take the form of sharing mission briefs and undertaking bilateral exchanges. On natural resource taxation, FAD will focus on providing core tax policy advice while the Bank focuses on long-term sector and capacity building support (see below).

15. Strengthening the financial sector. The Fund has funding from the Japanese government for a project to strengthen regional financial agencies in the CEMAC region. This will be closely coordinated with the Bank's program on financial sector TA to ensure complementarity.

16. Improving natural resource management. The Fund will provide TA on natural resource (mining) taxation/tax policy. The Bank will undertake sector-specific analysis linked to the government's agenda of economic growth and diversification, providing TA in the areas of mining, forestry and fisheries.

17. Extractive industries. The Bank will provide TA in the areas of: (i) the establishment of a national oil company; (ii) the mapping of main mining sites to be developed; (iii) the preparation of a new/revised mining code; and (iv) the preparation of a new/revised hydropower code. 
18. Areas where the Fund takes the lead and its analysis guides Bank-supported programs are in the dialogue on fiscal matters, which sets the envelope for public expenditures. The IMF leads the dialogue on policies to contain certain public expenditures, such as those regarding the public wage bill and definition of the ceiling for public investment. In these areas, the Bank ensures that its own policy advice is consistent with IMF recommendations. The IMF is also monitoring implementation of trade liberalization measures being taken at the CEMAC (regional) level. This supplements a significant program of Bank work to support regional integration among CEMAC countries. These measures should improve the business climate and will complement work by the Bank (in conjunction with the IFC) to facilitate investment.

19. Areas where there is no direct World Bank involvement relate to the dialogue on monetary policy, interest rates, the exchange rate, the balance of payments, and related statistical and measurement issues. 


\section{ANNEX III. Gabon: STATISTICAL ISSUES}

1. Data provision has some shortcomings, but is broadly adequate for surveillance. Staff's analysis is affected by shortcomings in the accuracy, reliability and adequacy of periodicity and timeliness for certain data, as well as consistency between datasets. The statistical producing agencies do not have sufficient access to source data and lack an institutional framework in which to share information and coordinate compilation efforts.

2. Gabon participates in the General Data Dissemination System (GDDS) but has not updated the metadata or plans for improvement since 2002. Except for consumer prices, the authorities do not report any real sector or government finance statistics (GFS) to STA for publication in International Financial Statistics (IFS) or for electronic dissemination. Detailed economic and financial statistics, including long historical time series, are published in the Tendances de l'Économie, issued twice a year by the General Directorate of Statistics and Economic Studies (DGSEE) of the Ministry of Economy, Trade, Industry, and Tourism. More recent sectoral developments are described in detail in the Tableau de Bord de l'Économie, issued quarterly by the Ministry of the Economy.

\section{National accounts}

3. Central AFRITAC (AFC) is working with authorities to incorporate the System of National Accounts 1993 methodological recommendations, particularly in the valuation of sectoral value added at basic prices. Coverage of developments in oil and other key export sectors is based on a range of indicators that may not fully capture the profits these sectors generate. Despite recent improvements in collecting and processing oil sector statistics, there are still significant inconsistencies between national accounts and balance of payments statistics. In addition, more frequent household surveys are required to improve the quality and quantity of data on income distribution and consumption. Two 2008 AFC missions have provided technical assistance on the treatment of statistics and fiscal statements (SFS), and the implementation of Access software for the SFS compilation. Efforts are needed to establish a more consistent database. The processing of the SFS of 2007 for the compilation of the national accounts of the same year is planned to be finalized by end-2008.

\section{Employment and unemployment}

4. Data on unemployment and the total labor force are not systematically available.

\section{Prices}

5. In 2007 the authorities began publishing an improved CPI index, which covers the same basket of goods and services as the CEMAC Harmonized Consumer Price Index (HCPI) and uses a weighting scheme derived from Gabon's 2005 household expenditure survey. However, it only covers the capital city of Libreville. 


\section{Government finance statistics}

6. A major shortcoming is limited institutional coverage, as social security operations are not included in the statement of operations of central or general government. Audited accounts of oil sector operations are generally available annually and sometimes quarterly, but with a significant reporting lag. Other needed improvements relate, inter alia, to the recording in the budget accounts of government-owned capital formation financed by oil companies and the recording of government domestic payment arrears.

\section{Monetary statistics}

7. The Bank of Central African States (BEAC) regularly reports in electronic form monthly monetary, interest rate, and exchange rate statistics for Gabon and other CEMAC member countries for publication in IFS, but delays occur sometimes in the submission of data. Institutional coverage of the monetary statistics for Gabon is comprehensive, but accuracy is affected by cross-border movements of currency among CEMAC member countries.

8. The BEAC started in mid-2007 a project to migrate monetary statistics of member countries of the CEMAC to the methodology in the Monetary and Financial Statistics Manual (MFSM). As part of this project, a regional workshop was organized by the BEAC in December 2007 to finalize the mapping of source data from commercial banks to the MFSM concepts and framework. STA participated in this workshop to provide guidance and advice. The BEAC has recently submitted test monetary data for Gabon using the standardized report forms for the period January 2000-December 2007.

\section{External public debt}

9. There are comprehensive data on the stock of external public debt and its composition, as well as detailed projections on debt service due. Data are provided, usually to Fund missions, by the General Directorate of Public Debt and Accounting (Direction générale de la comptabilité publique) of the Ministry of Economy, Finance, Budget, and Privatization.

\section{Balance of payments and trade statistics}

10. Balance of payments statistics are compiled by the national directorate of the BEAC and the estimates are validated by staff from BEAC headquarters. Data are disseminated with considerable delay, and the latest available official statistics are for 2006. Since 1995, compilation of balance of payments statistics has conformed to the Balance of Payments Manual, $5^{\text {th }}$ edition. Source data are collected through (i) surveys of enterprises by the central bank (the main source of data); (ii) reports from banks and the postal administration on foreign exchange transactions of other enterprises, retailers, and private individuals; and (iii) BEAC reports on banknote movements between Gabon and other BEAC countries. External trade data are mostly based on estimates, which are not cross-checked with customs 
data. Data on other items of the current account are not very reliable or accurate due to low response rates to enterprise surveys, despite partial correction through adjustments. Foreign direct investment in the financial account is likely to be underestimated owing to insufficient detail in the oil sector survey. The magnitude and detailed breakdown of private capital flows, particularly short term, suffer because data are not comprehensive. 


\section{Gabon: Table of Common Indicators Required for Surveillance}

(As of December 31, 2010)

\begin{tabular}{|c|c|c|c|c|c|}
\hline & $\begin{array}{c}\text { Date of } \\
\text { latest } \\
\text { observation }\end{array}$ & $\begin{array}{c}\text { Date } \\
\text { received }\end{array}$ & $\begin{array}{c}\text { Frequency } \\
\text { of } \\
\text { data }^{7}\end{array}$ & $\begin{array}{l}\text { Frequency } \\
\quad \text { of } \\
\text { reporting }^{7}\end{array}$ & $\begin{array}{l}\text { Frequency } \\
\text { of } \\
\text { publication }^{7}\end{array}$ \\
\hline Exchange Rates & Aug. 2010 & Aug. 2010 & $\mathrm{D}$ & $\mathrm{D}$ & $\mathrm{D}$ \\
\hline $\begin{array}{l}\text { International Reserve Assets and } \\
\text { Reserve Liabilities of the Monetary } \\
\text { Authorities }{ }^{1}\end{array}$ & Aug. 2010 & Nov. 2010 & $\mathrm{M}$ & $\mathrm{M}$ & $\mathrm{M}$ \\
\hline Reserve/Base Money & Aug. 2010 & Nov.2010 & $\mathrm{M}$ & $\mathrm{M}$ & $\mathrm{M}$ \\
\hline Broad Money & Aug. 2010 & Nov. 2010 & $\mathrm{M}$ & $\mathrm{M}$ & $\mathrm{M}$ \\
\hline Central Bank Balance Sheet & Aug. 2010 & Nov. 2010 & $\mathrm{M}$ & $\mathrm{M}$ & $\mathrm{M}$ \\
\hline $\begin{array}{l}\text { Consolidated Balance Sheet of the } \\
\text { Banking System }\end{array}$ & Aug. 2010 & $\begin{array}{l}\text { Nov. } \\
2010\end{array}$ & $\mathrm{M}$ & $\mathrm{M}$ & $\mathrm{M}$ \\
\hline Interest Rates $^{2}$ & Aug. 2010 & Aug. 2010 & $\mathrm{M}$ & $\mathrm{M}$ & $\mathrm{M}$ \\
\hline Consumer Price Index & $\begin{array}{l}\text { October. } \\
2010\end{array}$ & Nov.2010 & $\mathrm{M}$ & $\mathrm{M}$ & $\mathrm{M}$ \\
\hline $\begin{array}{l}\text { Revenue, Expenditure, Balance and } \\
\text { Composition of Financing }{ }^{3}-\text { General } \\
\text { Government }^{4}\end{array}$ & Sep. 2010 & Nov. 2010 & $\mathrm{M}$ & $\mathrm{Q}$ & $\mathrm{N} / \mathrm{A}$ \\
\hline $\begin{array}{l}\text { Revenue, Expenditure, Balance and } \\
\text { Composition of Financing }{ }^{3}-\text { Central } \\
\text { Government }\end{array}$ & Sep. 2010 & Nov. 2010 & $\mathrm{M}$ & Q & $\mathrm{N} / \mathrm{A}$ \\
\hline $\begin{array}{l}\text { Stocks of Central Government and } \\
\text { Central Government-Guaranteed Debt }\end{array}$ & Sep. 2010 & Nov. 2010 & Q & $\mathrm{Q}$ & $\mathrm{N} / \mathrm{A}$ \\
\hline External Current Account Balance & Dec. 2006 & Mar. 2010 & A & $\mathrm{I}$ & A \\
\hline $\begin{array}{l}\text { Exports and Imports of Goods and } \\
\text { Services }\end{array}$ & Dec. 2006 & Mar. 2010 & M & $\mathrm{M}$ & I \\
\hline GDP/GNP & 2008 & Dec. 2010 & $\mathrm{~A}$ & $\mathrm{I}$ & A \\
\hline Gross External Debt & Dec. 2009 & Mar. 2009 & $\mathrm{Q}$ & I & I \\
\hline International Investment Position $^{6}$ & $\mathrm{~N} / \mathrm{A}$ & $\mathrm{N} / \mathrm{A}$ & $\mathrm{N} / \mathrm{A}$ & $\mathrm{N} / \mathrm{A}$ & $\mathrm{N} / \mathrm{A}$ \\
\hline
\end{tabular}

${ }^{1}$ Includes reserve assets pledged or otherwise encumbered as well as net derivative positions.

${ }^{2}$ Both market-based and officially-determined, including discount rates, money market rates, rates on treasury bills, notes and bonds.

${ }^{3}$ Foreign, domestic bank, and domestic nonbank financing.

${ }^{4}$ The general government consists of the central government (budgetary funds, extra budgetary funds, and social security funds) and state and local governments.

${ }^{5}$ Including currency and maturity composition.

${ }^{6}$ Includes external gross financial asset and liability positions vis-à-vis nonresidents.

${ }^{7}$ Daily (D), Weekly (W), Monthly (M), Quarterly (Q), Annually (A); Irregular (I); Not Available (NA). 


\section{INTERNATIONAL MONETARY FUND}

EXTERNAL

Public Information Notice (PIN) No. 11/30 FOR IMMEDIATE RELEASE

March 4, 2011
International Monetary Fund

$70019^{\text {th }}$ Street, NW

Washington, D. C. 20431 USA

\section{IMF Executive Board Concludes 2010 Article IV Consultation with Gabon}

On February 18, 2011, the Executive Board of the International Monetary Fund (IMF) concluded the Article IV consultation with Gabon. ${ }^{1}$

\section{Background}

Gabon is recovering from the financial crisis. Low prices and weak demand for commodities shrank the fiscal and current account surpluses in 2009 and turned growth moderately negative. Real Gross Domestic Product is estimated to increase to 5.7 percent in 2010 and remain broadly at that level in 2011, reflecting public investment and a rebound in mining. Average annual inflation is projected to remain subdued. The non-oil primary deficit will deteriorate significantly, reflecting the increase in government investment and the fall in non-oil revenues. Economic activity is projected to remain robust in 2011, supported by mining, wood processing, and public investment. Inflation is forecast to pick up, mostly driven by higher food and energy prices. The foremost risk to the economic outlook is a decline in oil and manganese prices, because these commodities accounted for about 90 percent of total exports of goods and 45 percent of nominal GDP on average during the last decade.

\footnotetext{
${ }^{1}$ Under Article IV of the IMF's Articles of Agreement, the IMF holds bilateral discussions with members, usually every year. A staff team visits the country, collects economic and financial information, and discusses with officials the country's economic developments and policies. On return to headquarters, the staff prepares a report, which forms the basis for discussion by the Executive Board. At the conclusion of the discussion, the Managing Director, as Chairman of the Board, summarizes the views of Executive Directors, and this summary is transmitted to the country's authorities. An explanation of any qualifiers used in summings up can be found here: http://www.imf.org/external/hp/sec/misc/qualifiers.htm.
} 
To improve the quality of spending and release resources for growth-enhancing spending and social outlays, the government is strengthening public financial management. Reforms to enhance the business environment for private sector promotion focus on abolishing burdensome regulations involving lengthy procedures. Also, to facilitate access to financial services, work is ongoing to finalize the microfinance medium-term strategy.

Looking ahead, the government aims to transform Gabon into an emerging economy through diversification away from oil and promotion of a business friendly environment.

\section{Executive Board Assessment}

Executive Directors welcomed that Gabon is on a path of recovery from the global crisis. Looking ahead, the key challenge will be preparing the economy for the post-oil period through economic diversification, increased external competitiveness, and poverty reduction. Directors stressed the importance of maintaining long-term fiscal sustainability, improving the business environment, and strengthening the financial sector as key pillars of the authorities' strategy to transform Gabon into an emerging economy.

Directors emphasized that, as oil reserves dwindle, sustained fiscal consolidation, while addressing Gabon's substantial development needs, is crucial. Annual budgets need to be linked to longer-term policies and to making progress toward fiscal sustainability. Capital spending should be anchored in a realistic multiyear investment plan and a credible medium-term fiscal strategy to safeguard macroeconomic stability. A number of Directors saw scope in the short term for accelerating fiscal consolidation, while at the same time scaling up infrastructure and health and education investment. A few other Directors saw merit in a more gradual adjustment.

Directors welcomed the authorities' intention to strengthen public financial management to improve the quality of spending and release resources for growth-enhancing spending and social outlays. Reforms to refocus public investment on key infrastructure and social projects and to strengthen the appraisal, selection, and monitoring of projects are a priority. Directors also stressed the importance of enhanced transparency and accountability in the management of resources from the country's extractive sector, in particular with respect to the new funds under consideration.

Directors noted the staff's assessment that the real effective exchange rate appears broadly in line with fundamentals. At the same time, they encouraged the authorities to step up efforts to enhance external competitiveness. To address the poor performance of the non-oil sector, structural reforms are needed to improve the business climate, build basic infrastructure, enhance health and education services, and increase labor market flexibility.

Directors underlined that limited access to financial services remains a serious obstacle to private sector development. They considered that priority should be given to improving the institutional and regulatory environment, in particular for small and medium enterprises. 
3

Directors advised the authorities to eliminate as soon as possible the tax on wire transfers, which gives rise to an exchange restriction under Article VIII.

Directors encouraged the authorities to further improve the quality of economic and financial data, making use of technical assistance from the Fund and donors.

Public Information Notices (PINs) form part of the IMF's efforts to promote transparency of the IMF's views and analysis of economic developments and policies. With the consent of the country (or countries) concerned, PINs are issued after Executive Board discussions of Article IV consultations with member countries, of its surveillance of developments at the regional level, of post-program monitoring, and of ex post assessments of member countries with longer-term program engagements. PINs are also issued after Executive Board discussions of general policy matters, unless otherwise decided by the Executive Board in a particular case. 


\section{Gabon: Selected Economic Indicators, 2008-15}

\begin{tabular}{|c|c|c|c|c|c|c|c|c|}
\hline \multirow[b]{4}{*}{ Production, prices, and money } & \multicolumn{5}{|c|}{20082009201020112012} & 2013 & \multicolumn{2}{|c|}{20142015} \\
\hline & \multicolumn{3}{|c|}{ Est. } & \multicolumn{5}{|c|}{ Proj. } \\
\hline & \multicolumn{8}{|c|}{ (Annual percent change, unless otherwise indicated) } \\
\hline & & & & & & & & \\
\hline Real GDP & 2.3 & -1.4 & 5.7 & 5.6 & 3.3 & 1.6 & 2.6 & 2.5 \\
\hline Oil & -1.4 & -4.5 & 4.1 & 1.5 & $-0.8-$ & -6.1 & -0.6 & -0.7 \\
\hline Non-oil & 3.4 & -0.5 & 6.1 & 6.7 & 4.3 & 3.6 & 3.3 & 3.2 \\
\hline Consumer prices (average) & 5.3 & 2.1 & 0.4 & 2.3 & 3.4 & 3.1 & 3 & 3 \\
\hline Terms of trade (deterioration $=-$ ) & 13.4 & -22.6 & 11 & 1.6 & 1.8 & 0.4 & 0.4 & \\
\hline Broad Money & 8.8 & 2.2 & 8.3 & 9.2 & 9.5 & 10.5 & 6.1 & \\
\hline
\end{tabular}

Government operations

$\begin{array}{lllllllll}\text { Overall balance (commitment basis) } & 11.4 & 6.5 & 4.8 & 5 & 6.1 & 5 & 5.5 & 5.8\end{array}$ Non-oil primary balance (percent of non-oil GDP) $-14.8-13.9-21.1-22.5-18.7 \quad-16.7 \quad-15.1 \quad-14$

External sector

External current account balance (with official transfers)

$\begin{array}{llllllll}23.3 & 7.9 & 10.5 & 11.6 & 10.2 & 6.2 & 6 & 5.2\end{array}$

External public debt $\begin{array}{llllllll}15.6 & 18.8 & 15.7 & 14.3 & 13.1 & 12.6 & 12.2 & 11.7\end{array}$

Sources: Gabonese authorities and IMF staff estimates and projections. 


\section{Statement by Kossi Assimaidou, Executive Director for Gabon February 18, 2011}

On behalf of my authorities, I would like to express my appreciation to the Executive Board, Management, and staff for their continued advice and assistance to Gabon. My authorities particularly welcome the discussions held with staff during their visits to Gabon in March and November 2010. My authorities appreciate staff recommendations and inputs in their economic development plan for the post-oil era.

\section{Recent developments}

After turning negative in 2009 due to the global economic crisis, real GDP growth is estimated at 5.7 percent in 2010 and is projected to remain at the same level in 2011, driven by the strong public demand and a rebound in the mining sector. Inflation remained low in 2010 but is expected to increase in 2011 owing to higher food and energy prices. The financial sector weathered the global crisis well and the banking system remains profitable.

The country went through a political transition in 2009, marked by the election of a new president in August 2009. Upon taking office, the new authorities gave their attention to the significant long-term challenges facing Gabon, including the achievement of high and sustained non-oil growth and improving social indicators in a context of dwindling oil reserves.

To address these challenges, my authorities developed and rolled out an economic development plan aimed at reducing the country's dependence on oil through economic diversification. This plan encompasses a series of institutional and structural reforms covering a wide range of areas, as well as a vast public investment program aimed at strengthening basic infrastructure in the country. Its main objectives are to support non-oil private sector development and improve the quality of life for the Gabonese population.

\section{Fiscal performance and sustainability}

In 2009 and 2010, my authorities took strong measures to reduce nonessential expenditures. In particular, they carried out a census of civil servants to detect and eliminate ghost workers from the public payroll. In addition, they have significantly reduced the number of high-level positions in the civil service. Savings from these measures have enabled the authorities to notably accelerate the hiring of new workers in the health, education and security sectors. The investment program in 2010 focused on the rehabilitation and development of transport, energy, and communication infrastructure. In the health and education sectors, new classrooms are being built and health infrastructure is being upgraded.

Overall, the implementation of the economic program increased total spending by 4.9 percent of GDP in 2010, which has been accommodated by higher oil revenue (4.5 percent of GDP) stemming from higher oil production and prices. However, while the overall balance remains in surplus, the non oil primary deficit (NOPD) widened from 14 percent of non-oil GDP in 2009 to 21.1 percent in 2010 . 
My Gabonese authorities recognize the need to maintain fiscal prudence and sustainability going forward, in order to preserve macroeconomic stability and the country's external competitiveness, and hence achieve their development goals. My authorities fully subscribe to staff's recommendations to avoid a procyclical fiscal policy and bring the NOPD down to a more sustainable level over the medium-term. However, they stress that the level of expenditures is expected to remain high during the implementation of the public investment program over the next few years. They are currently preparing a medium-term expenditure framework which aims to gradually lower the NOPD, notably by reducing gradually capital spending, pursuing wage and employment reforms, and pursuing the rationalization of expenditures on goods and services as well as transfers and subsidies.

My authorities also believe that ongoing tax and customs administration reforms and a better control of tax exemptions will strengthen non-oil revenue over time. They stress that the tax exemptions already granted in the context of the special economic zone (SEZ) will expire according to the law. They are of the view that the impact of the SEZ on growth and eventually on fiscal revenue will outweigh the corresponding tax expenditures. Regarding specifically the tax on wire transfers, my authorities are working to resolve this issue. However, reforming this tax is politically sensitive due to the fact that proceeds from this tax contribute to the financing of the health insurance fund.

In order to strengthen public financial management, my authorities introduced program budgeting and adopted modern principles of financial management to become effective in 2012, as recommended by Fund TA mission. They are now holding weekly meetings to monitor investment-related payments, in order to avoid any accumulation of arrears and strengthen accountability. On the new institutions being created, they will ensure that they are not of an extra-budgetary nature and that they have strong governance structures.

My authorities intend to pursue a proactive debt policy, consistent with the 2011-2013 debt strategy adopted with the 2011 budget. In light of the findings of the debt sustainability analysis, this strategy limits the annual amount of new debt to be contracted by the government and defines criteria for contracting new loans. The framework for debt management has been strengthened with the creation of a Directorate General of Debt and the establishment of a national committee on public debt.

\section{Public Investment Program}

The public investment program aims at addressing infrastructure needs in the country. In particular, the selection of infrastructure projects will be guided by the need to boost and link the five geographical development centers identified in the development plan as having specific potential in sectors that are deemed essential for the diversification of the economy. Consistent with this approach, the SEZ being established will offer developed infrastructure and various incentives for the timber industry to invest in the local processing of logs and export of high value-added wood products. 
In order to strengthen public investment management, a national agency for major public works was set up, entrusted with the planning, management, and implementation of large public infrastructure projects. This agency is benefiting from foreign technical expertise. In addition, a service contract was signed in November 2010 with the World Bank to enhance national capacities in this area.

\section{Financial Sector Reforms}

In the financial sector, my authorities recognize the important role that an efficient credit system can play in the development of the economy. In this respect, they are undertaking reforms to strengthen the credit infrastructure. These reforms include improved mechanisms and procedures to settle loan contract disputes, streamlined procedures for the realization of guarantees to obtain loans, and creation of a corporate balance sheet centralization system at the central bank that provides commercial banks access to companies' balances. Also, they have streamlined the number of state-owned and sponsored financial institutions involved in SMEs and housing financing through notably mergers and restructuring, and appointed new top management teams. Work is also ongoing to finalize the microfinance development strategy and expand access to credit, while limiting operational and security risks. Going forward, Gabon intends to subscribe to the capital of the African Guarantee and Economic Cooperation Fund, which guarantees bank loans to SMEs. My authorities believe that all these actions will contribute to lower financing costs and increase access to financial services by SMEs and households.

\section{Other Structural Reforms}

Along with building infrastructure and reforming the financial sector, improving the business environment is a central piece of my authorities' plan to promote private sector development and enhance the country's long-term growth prospects. In this regard, my authorities signed a service agreement with the International Finance Corporation (IFC) in November 2010 to help the government identify the necessary measures to abolish burdensome regulations involving lengthy procedures, based on the analysis of the World Bank's Doing Business. They also streamlined the number of government agencies involved in export and investment promotion and set up a competition authority which will ensure that the free play of competition is not hampered by illicit price-setting arrangements, notably in the retail market.

My authorities are also reforming the oil sector. A national oil company is being created and the Fund for Future Generations has been converted into a Strategic Sovereign Fund that will, among other things, enable the government to take equity stakes in companies of strategic importance for Gabon.

The public administration is also being revamped. Organizational structures of ministerial departments are being modified and their mandates are being updated.

\section{Money and Exchange Rate}


Gabon is a member of the Central African Economic and Monetary Community (CEMAC). The regional currency, the CFA franc, is pegged to the euro. The membership in the CEMAC has served the economy well, and monetary policy has been appropriate and prudent. As noted above, the Gabonese authorities will continue their structural reform efforts to improve the competitiveness of the economy.

\section{Conclusion}

Gabon is facing the significant long-term challenges of achieving high and sustained non-oil growth and improving social indicators in a context of dwindling oil reserves. To address this challenge, my authorities have embarked on an economic development plan aimed at reducing the country's dependence on oil through economic diversification. Aware of the existing capacity constraints in the country and in order to ensure a sound, well-sequenced and cost-efficient implementation of their plan, my authorities have actively sought the technical expertise of reputable international organizations and corporations, including the Fund, the World Bank and the IFC. They remain determined to preserve macroeconomic stability going forward and will adapt their fiscal policy framework accordingly, notably by developing a medium-term fiscal framework. 